\title{
DEVELOPMENT OF HISTORIC AND SYNTHESIZED UNREGULATED STREAMFLOW FOR THE JAMES RIVER IN NORTH DAKOTA AND SOUTH DAKOTA, 1983-91
}

By Douglas G. Emerson and Colin A. Niehus

\section{U.S. GEOLOGICAL SURVEY}

Water-Resources Investigations Report 94-4018

Prepared in cooperation with the U.S. Bureau of Reclamation 


\title{
U.S. DEPARTMENT OF THE INTERIOR BRUCE BABBITT, Secretary
}

\author{
U.S. GEOLOGICAL SURVEY
}

Robert M. Hirsch, Acting Director

Any use of trade, product, or firm names is for descriptive purposes only and does not imply endorsement by the U.S. Government.

For additional information write to:

\section{District Chief}

U.S. Geological Survey

Water Resources Division

821 East Interstate Avenue

Bismarck, ND 58501-1199
Copies of this report can be purchased from:

U.S. Geological Survey

Earth Science Information Center

Open-File Reports Section

Box 25286, Mail Stop 517

Denver Federal Center

Denver, CO 80225-0425 


\section{CONTENTS}

Page

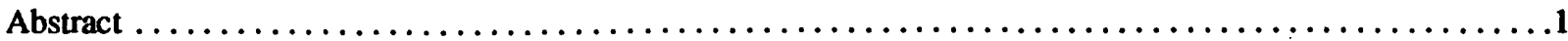

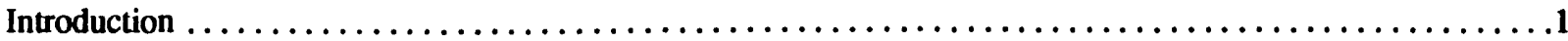

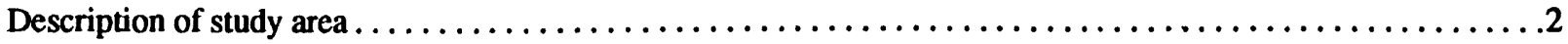

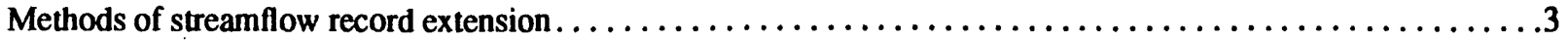

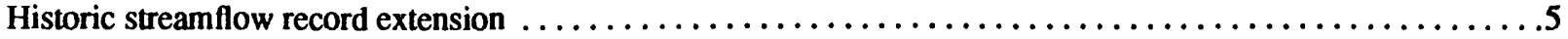

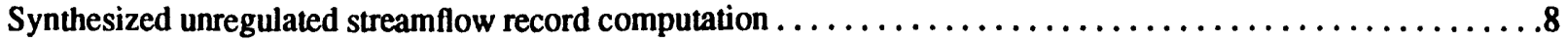

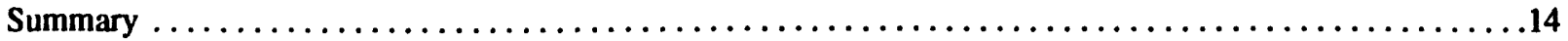

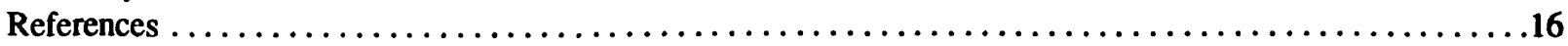

Supplement 1. Measured and synthesized historic streamflow for gaging stations on the James River in

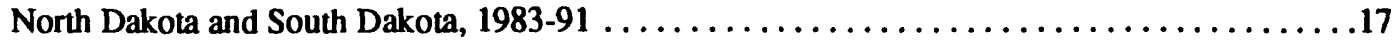

2. Synthesized unregulated streamflow for gaging stations on the James River in

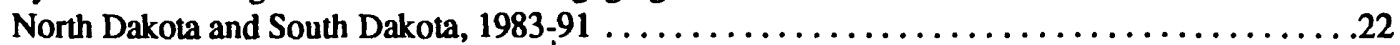

3. Surface-water withdrawals from and wastewater returns to the James River in

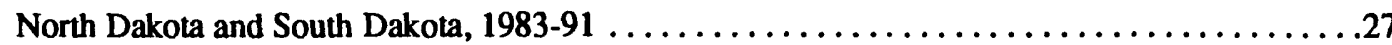

\section{PLATE}

Plate 1. Map showing James River Basin and locations of selected streamflow-gaging stations,

North Dakota and South Dakota. (in pocket)

\section{TABLES}

Table 1. Selected streamflow-gaging stations operated by the U.S. Geological Survey in the James River Basin, North Dakota and South Dakota. .........................6

2. Monthly regression equations used to compute the synthesized historic streamflow for the James River near Stratford, South Dakota ............................

3. Monthly regression equations used to compute the synthesized historic streamflow for the James River near Mitchell, South Dakota .8 


\section{CONVERSION FACTORS}

\begin{tabular}{lcl}
\hline Muttlply & By & To obtain \\
\hline acre-foot & 1,233 & cubic meter \\
cubic foot per second & 0.02832 & cubic meter per second \\
foot & 0.3048 & meter \\
foot per mile & 0.1894 & meter per kilometer \\
mile & 1.609 & kilometer \\
square mile & 2.590 & square kilometer \\
\hline
\end{tabular}




\title{
Development of Historic and Synthesized Unregulated Streamflow for the James River in North Dakota and South Dakota, 1983-91
}

\author{
By Douglas G. Emerson and Colin A. Niehus
}

\begin{abstract}
Operation of the Garrison Diversion Unit may have some affect on the hydrology of the James River in North Dakota and South Dakota. The Garrison Diversion Unit Monthly Operations Model was developed to analyze a wide range of streamflow conditions that could occur in the James River Basin. The purpose of this study was to compute monthly streamflows that are required as input to the model.

Historic streamflow data were complied and record extension methods were used, when necessary, to compute monthly streamflow for 1983-91 for 15 gaging stations on the James River in North Dakota and South Dakota. The record extension methods used include Maintenance of Variance Extension Type 1, Ordinary Least Squares, and drainage-area ratio.

In addition to the historic streamflow, synthesized unregulated streamflow was computed for the 15 gaging stations on the James River for 1983-91 by eliminating the effects of Jamestown Reservoir, Pipestem Reservoir, Sand Lake National Wildlife Refuge, consumptive surface-water withdrawals, and wastewater withdrawals. Maintenance of Variance Extension Type 1, Ordinary Least Squares regression, water-balance procedures, and drainage-area ratio method were used to compute the unregulated streamflows.

\section{INTRODUCTION}

In September 1983, a technical team consisting of members from the U.S. Bureau of Reclamation, U.S. Fish and Wildlife Service, U.S. Geological Survey, North Dakota State Water Commission, South Dakota Department of Water and Natural Resources, and Garrison Conservancy District met to discuss issues related to the hydrology of the James River Basin in North Dakota and South Dakota. The discussion focused on how to best analyze the effects that operation of the Garrison Diversion Unit might have on the hydrology of the James River in North Dakota and South Dakota. The Garrison Diversion Unit in North Dakota was authorized by Congress in 1965 to provide for irrigation, municipal and industrial water, fish and wildlife, recreation, and flood control. Although earlier studies to analyze the effects of the Garrison Diversion Unit on the hydrology of the James River have been completed by the U.S. Bureau of Reclamation, results obtained by using the Hydrologic River Operation Study System differed from those obtained by using the Retum Flow Models (U.S. Department of the Interior, 1983, page III-20). Because of the limitations of existing streamflow models, the technical team concluded that a new model was needed to analyze a wide range of streamflow conditions and the resulting hydrologic conditions that could be expected to occur in the James River Basin.
\end{abstract}


The model, Garrison Diversion Unit Monthly Operations Model, developed by the U.S. Bureau of Reclamation required, as input data, the monthly unregulated streamflows at 13 gaging stations on the James River for 1953-82. Results of a study conducted to compile and analyze the 1953-82 monthly streamflow data needed as input to the model were published by Wiche, Benson, and Emerson (1989). Since the model was developed, two additional gaging stations have been installed on the James River, and an additional 9 years of stream flow data are available for many of the stations. Consequently, the U.S. Bureau of Reclamation needed an updated data set for the model. Streamflow data of different record lengths are available for the $\mathbf{1 5}$ gaging stations along the James River in North Dakota and South Dakota.

This report provides the results of a study to compile and estimate the 1983-91 monthly streamflow data needed as input to the Garrison Diversion Unit Monthly Operations Model developed by the U.S. Bureau of Reclamation. The specific objectives of this study were as follow:

(1) Compile and extend the streamflow record where necessary to develop 1983-91 monthly streamflow for the following 15 gaging stations on the James River (pl. 1, in pocket)

\begin{tabular}{l} 
Station number \\
\hline 06468170 \\
06468250 \\
06468500 \\
06470000 \\
06470500 \\
06470878 \\
06471000 \\
06472000 \\
06473000 \\
06475000 \\
06476000 \\
06477000 \\
06478000 \\
06478500 \\
06478513
\end{tabular}

Station name
James River near Grace City, N. Dak.;
James River above Arrowwood Lake near Kensal, N. Dak.;
James River near Pingree, N. Dak.;
James River at Jamestown, N. Dak.;
James River at LaMoure, N. Dak.;
James River at North Dakota-South Dakota State line;
James River at Columbia, S. Dak.;
James River near Stratford, S. Dak.;
James River at Ashton, S. Dak.;
James River near Redfield, S. Dak.;
James River at Huron, S. Dak.;
James River near Forestburg, S. Dak.;
James River near Mitchell, S. Dak.;
James River near Scotland, S. Dak.;
James River near Yankton, S. Dak.; and

(2) estimate 1983-91 monthly unregulated streamflows by using statistical or water-balance methods for all 15 gaging stations identified in item 1.

In this study, an attempt was made to provide reasonable estimates of streamflow in terms of means and variances of the flow. However, the methods employed do not attem.-it to preserve the interstation correlation of streamflow values on the James River.

\section{DESCRIPTION OF STUDY AREA}

The James River, about 747 miles in total length, drains parts of east-central North Dakota and South Dakota (pl. 1). The James River Basin encompasses about 22,000 square miles, of which 8,000 square miles is in North Dakota and 14,000 square miles is in South Dakota. The headwaters of the James River are located in Wells County, N. Dak. From these headwaters, the James River extends about 100 miles to Arrowwood National Wildlife Refuge. Streamflow is low or nonexistent much of the year from the headwaters to the refuge. Jamestown Reservoir, located in a narrow valley immediately downstream of the 
refuge, was created by the completion of Jamestown Dam in 1953. Pipestem Creek, a major tributary to the James River, enters the James River 1 mile downstream of Jamestown Dam. Pipestem Creek has been regulated since the completion of Pipestem Dam and Reservoir in 1974.

Downstream from Jamestown Dam, the James River meanders within the confines of a broad valley for about 135 miles to near the North Dakota-South Dakota State line. Near the State line, the James River enters the lakebed of glacial Lake Dakota and flows through Dakota Lake National Wildlife Refuge and Sand Lake National Wildlife Refuge. Both refuges were created by construction of low-head dams. The water-surface elevation in Dakota Lake National Wildlife Refuge is regulated by a low-head concrete dam control and the total storage capacity is about 3,200 acre-feet. The water-surface elevation in Sand Lake National Wildlife Refuge is regulated by two control structures, and the total storage capacity is about 27,200 acre-feet. After leaving Sand Lake National Wildlife Refuge, the river flows through the Lake Dakota Plain for about 150 miles to Redfield, S. Dak. Within parts of the Lake Dakota Plain, the slope of the river is less than 0.1 foot per mile and the channel capacity is as little as 200 cubic feet per second. Downstream from Redfield, S. Dak., the slope and channel capacity increase. The elevation of the river decreases about 130 feet in 474 river miles within South Dakota.

Several other dams in addition to the low-head dams are located on the James River in South Dakota. The Tacoma Park and Spink County Dams are used primarily for recreation. Two dams near Huron, the James Diversion Dam and the Third Street Dam provide the city of Huron's major water supply. Most of the smaller dams were constructed privately and are used as river crossings or as diversion points for private irrigation.

\section{METHODS OF STREAMFLOW RECORD EXTENSION}

Record extension of measured streamflow or synthesized unregulated streamflow can be accomplished by several methods, including use of drainage-area ratio, regional statistics, regression, and precipitation-runoff modeling. The drainage-area ratio method (Hirsch, 1979) is based on the assumption that the ratio of the flows at two sites is equal to the ratio of their drainage areas by using the following equation:

$$
\tilde{y}_{i}=\left(\frac{a_{y}}{a_{x}}\right) x_{i}
$$

where $\tilde{y}_{i}$ is the estimated flow during month $i$ at the site of interest, in cubic feet per second;

$a_{y}$ is the drainage area at the site of interest, in square miles;

$a_{x}$ is the drainage area at the base station, in square miles; and

$x_{i}$ is the gaged flow during month $i$ at the base station, in cubic feet per second.

If there are no records of streamflow at the site of interest or no reliable regional flow statistics, the assumption that the flow is proportional to the drainage area may be the best assumption to make.

The regional-statistics method (Thomas and Benson, 1970) uses regional regression equations developed between streamflow and basin characteristics to estimate mean monthly flows. The equations have not been developed for North Dakota and South Dakota, and their development was not within the scope of this study. Therefore, this method was not used.

Regression methods can be used to extend streamflow records in time. Regression methods are based on the assumption that streamflow records are available at the site of interest for a period of $N_{1}$ years, and records at the base station are available for the same $N_{1}$ years, plus an additional $N_{2}$ years. The use of untransformed data or logarithms to extend records was studied by Hirsch (1979) and Stedinger (1980). The conclusion reached by both Hirsch and Stedinger was to work with logarithms. 
Ordinary Least Squares (OLS) regression can be used to estimate streamflow at the site of interest by using the following equation:

$$
\tilde{y}_{i}=a+b x_{i}
$$

where $\tilde{y}_{i}$ and $x_{i}$ are defined before. The parameters $a$ and $b$ are those values that minimize the squared errors. The solution of equation 2 becomes

$$
\tilde{y}_{i}=m\left(y_{1}\right)+r\left[\frac{s\left(y_{1}\right)}{s\left(x_{1}\right)}\right]\left[x_{i}-m\left(x_{1}\right)\right]
$$

where $m\left(y_{1}\right)$ is the sample mean of $N_{1}$ years of gaged flow at the site of interest, in cubic feet per second;

$r$ is the sample product-moment correlation coefficient between the $N_{1}$ concurrent measurements of $x$ and $y$;

$s\left(y_{1}\right)$ is the sample standard deviation of $N_{1}$ years of streamflow at the site of interest, in cubic feet per second;

$s\left(x_{1}\right)$ is the sample standard deviation of $N_{1}$ years of streamflow at the base station, in cubic feet per second; and

$m\left(x_{1}\right)$ is the sample mean of $N_{1}$ years of streamflow at the base station, in cubic feet per second.

If the natural logarithms of the discharges are used in equation 2, then equation 3 becomes

$$
\ln \tilde{y}_{i}=m_{l}\left(y_{1}\right)+r_{l}\left[\frac{s_{l}\left(y_{1}\right)}{s_{l}\left(x_{1}\right)}\right]\left[\ln x_{i}-m_{l}\left(x_{1}\right)\right]
$$

where $m_{l}\left(y_{1}\right)$ is the sample mean of $N_{l}$ years of the natural logarithms of gaged flow at the site of interest,

$r_{l}$ is the sample product-moment correlation coefficient between the $N_{1}$ concurrent measurements of the natural logarithms of $x$ and $y$;

$s_{l}\left(y_{1}\right)$ is the sample standard deviation of $N_{1}$ years of the natural logarithms of streamflow at the site of interest,

$s_{l}\left(x_{1}\right)$ is the sample standard deviation of $N_{1}$ years of the natural logarithms of streamflow at the base station, and

$m_{l}\left(x_{1}\right)$ is the sample mean of $N_{1}$ years of the natural logarithms of streamflow at the base station.

Matalas and Jacobs (1964) indicated that the sample mean, $m\left(y_{1}\right)$, is an unbiased estimate of the population mean, $\mu_{y}$, but the sample variance, $s^{2}\left(y_{1}\right)$, is a biased estimate of the population variance, $\sigma^{2}$.

Another regression method used to extend streamflow records in time is the Maintenance of Variance Extension Type 1 (MOVE.1) described by Hirsch (1982). MOVE.1 uses the same equation (eq. 2) as OLS, but the parameters $a$ and $b$ are determined so that the mean and variance estimated by using equation 2 over the period $N$ would equal the sample mean and variance. The solution of equation 2 becomes

$$
\tilde{y}_{i}=m\left(y_{1}\right)+\left[\frac{s\left(y_{1}\right)}{s\left(x_{1}\right)}\right]\left[x_{i}-m\left(x_{1}\right)\right] .
$$


Equations 3 and 5 differ simply by the $r$ term included in equation 3. Monte Carlo and empirical experiments with actual streamflow records by Hirsch (1982) indicated that, even for a relatively small sample size, the MOVE. 1 equation tends to produce a less biased estimate of the variance of an extended streamflow record than does OLS regression. A complete development of the MOVE.1 and OLS equations is presented by Hirsch (1982) and Alley and Bums (1983).

The reason for record extension is to produce a time series that is relatively long and possesses the same statistical characteristics as those of the actual record. Hirsch (1982) demonstrated that the MOVE.1 equation procedure preserves the statistical characteristic of the actual record better than the OLS procedure.

Alley and Burns (1983) developed a means of selecting monthly extension equations either by using flow values only from the same month, or developing the extension equation by using all flow values. The selection involves a tradeoff between the ability to preserve monthly differences versus greater sample size. The MOVE.1 equation (Alley and Burns, 1983) has an option that allows for both cyclic (monthly) and noncyclic (annual) extension equations to be considered for each individual prediction. If the cyclic option is selected, an extension equation is computed for that month by using only streamflow values for the same month; if the noncyclic option is selected, an extension equation is computed by using all concurrent streamflow values for the period of record.

For a particular month, the missing value for the site of interest is estimated by using both the cyclic equation and the noncyclic equation, and a standard error of prediction is computed for both estimates. The equation that provides the smallest standard error of prediction is used to estimate the missing value.

A precipitation-runoff model is another viable method for developing a time series for flows at a site. The method requires development and calibration of a precipitation-runoff model that can simulate snowmelt and rainfall runoff. A calibrated model does not exist for the areas of interest, and the calibration of such a model was not within the scope of this study.

In this study, a combination of drainage-area ratio and regression methods was used to extend the streamflow records. In most cases, hydrologic judgment was used to select the best extension techniques.

\section{HISTORIC STREAMFLOW RECORD EXTENSION}

Historic streamflow, as used in this report, refers to the measured monthly streamflow and, if necessary, the synthesized monthly streamflow for January 1983 through December 1991. Synthesized historic streamflows reflect the effects of the water-impounding structures now in place in the James River Basin. Stream flow records are available for 1983-91 for 10 of the 15 James River main-stem gaging stations. Five gaging stations--James River above Arrowwood Lake near Kensal, James River near Pingree, James River near Stratford, James River near Redfield, and James River near Mitchell--were not operated for all or part of 1983-91. Therefore, synthesized streamflows were required for these stations. The record extension method used for each of these five gaging stations is described in the following text. The same method that was used by Wiche, Benson, and Emerson (1989) is used whenever possible. Historic streamflow for 1983-91 for the 15 James River gaging stations (pl. 1 and table 1) is listed in supplement 1.

James River above Arrowwood Lake near Kensal.--Historic streamflow record for the James River above Arrowwood Lake near Kensal (station 2 on pl. 1 and in table 1) is not available for January 1983 through September 1985. The drainage-area ratio method was used to compute the historic streamflow. Historic streamflow for the James River near Grace City was multiplied by 1.10 to account for a 10-percent increase in contributing drainage area between the James River near Grace City and the James River above Arrowwood Lake near Kensal. 
Table 1. Selected streamflow-gaging stations operated by the U.S. Geological Survey in the James River Basin, North Dakota and South Uakota

[--, streamflow data not required for model inpul $]$

\begin{tabular}{|c|c|c|c|c|c|}
\hline \multirow{2}{*}{\multicolumn{2}{|c|}{ Station number }} & \multirow[b]{2}{*}{ Station name } & \multicolumn{2}{|c|}{$\begin{array}{l}\text { Drainage area } \\
\text { (square miles) }\end{array}$} & \multirow[b]{2}{*}{ Perlod of record } \\
\hline & & & Total & $\begin{array}{c}\text { Non- } \\
\text { contributing }\end{array}$ & \\
\hline 1 & 06468170 & James River near Grace City, N. Dak. & 1,060 & 650 & $6 / 68$ to present. \\
\hline 2 & 06468250 & $\begin{array}{l}\text { James River above Arrowwood Lake near } \\
\text { Kensal, N. Dak. }\end{array}$ & 1,200 & 750 & $10 / 85$ to present. \\
\hline 3 & 06468500 & James River near Pingree, N. Dak. & 1,670 & 988 & $10 / 52$ through $9 / 68$. \\
\hline-- & 06469400 & Pipestem Creek near Pingree, N. Dak. & 700 & 440 & $10 / 74$ to present. \\
\hline 4 & 06470000 & James River at Jamestown, N. Dak. & 2,820 & 1,650 & $4 / 43$ to present. \\
\hline 5 & 06470500 & James River at LaMoure, N. Dak. & 4,390 & 2,600 & $4 / 50$ to present. \\
\hline-- & 06470800 & Bear Creek near Oakes, N. Dak. & 357 & 255 & $10 / 76$ to present. \\
\hline-- & 06470875 & James River at Ludden Dam, N. Dak. & 5,480 & 3,300 & $10 / 81$ to present. \\
\hline 6 & 06470878 & $\begin{array}{l}\text { James River at North Dakota-South } \\
\text { Dakota State line }\end{array}$ & 5,480 & 3,300 & $10 / 81$ to present. \\
\hline- & 06470980 & James River near Hecla, S. Dak. & 5,520 & 3,310 & $2 / 82$ to present. \\
\hline 7 & 06471000 & James River at Columbia, S. Dak. & 5,860 & 3,380 & $10 / 45$ to present. \\
\hline-- & 06471200 & $\begin{array}{l}\text { Maple River at the North Dakota-South } \\
\text { Dakota State line }\end{array}$ & 750 & 270 & $6 / 56$ to present. \\
\hline 8 & 06472000 & James River near Stratford, S. Dak. & 8,860 & 4,010 & $3 / 50$ through $9 / 72$. \\
\hline 9 & 06473000 & James River at Ashton, S. Dak. & 9.740 & 4,070 & $10 / 45$ to present. \\
\hline 10 & 06475000 & James River near Redfield, S. Dak. & 13,900 & 4,120 & $3 / 50$ through $9 / 90$. \\
\hline 11 & 06476000 & James River at Huron, S. Dak. & 15,900 & 4,150 & $\begin{array}{l}8 / 28 \text { to } 9 / 32 \\
8 / 43 \text { to present. }\end{array}$ \\
\hline 12 & 06477000 & James River near Forestburg, S. Dak. & 17,600 & 4,150 & $3 / 50$ to present. \\
\hline 13 & 06478000 & James River near Mitchell, S. Dak. & 19,100 & 4,150 & $\begin{array}{l}7 / 53 \text { through } 9 / 58 \text {, } \\
8 / 65 \text { through } 9 / 72 \text {. }\end{array}$ \\
\hline 14 & 06478500 & James River near Scotland, S. Dak. & 20,700 & 4,150 & $9 / 28$ to present. \\
\hline 15 & 06478513 & James River near Yankton, S. Dak. & 20,900 & 4,150 & 10/81 to present. \\
\hline
\end{tabular}

James River near Pingree.--Historic streamflow record for the James River near Pingree (station 3 on pl. 1 and in table 1) is not available for January 1983 through December 1991. The drainage-area ratio method was used to compute the historic streamflow. Historic streamflow for the James River above Arrowwood Lake near Kensal was multiplied by 1.52 to account for a 52-percent increase in contributing drainage area between the James River above Arrowwood Lake near Kensal and the James River near 
Pingree. The historic streamflow for the James River above Arrowwood Lake near Kensal for January 1983 through September 1985 was computed; and therefore, additional uncertainty will result in the historic streamflow for the James River near Pingree.

James River near Stratford.--Historic streamflow record for the James River near Stratford (station 8 on pl. 1 and in table 1) is not available for January 1983 through December 1991. OLS regression was used to compute historic streamflow because of the strong correlation between concurrent measured streamflow at this site and measured streamflow for the James River at Ashton. Because the distribution of measured streamflows for the James River near Stratford is skewed to the right, as indicated by a larger mean flow (113 cubic feet per second) than median flow (16 cubic feet per second), a natural log transformation of data was used. The correlation coefficients and regression equations used to compute the streamflow for the James River near Stratford $\left(Q_{h-\text { str }}\right)$ by using the streamflow for the James River at Ashton $\left(Q_{h-a}\right)$ are listed in table 2 . For those months when the streamflow for the James River at Ashton was zero, the streamflow for the James River near Stratford was set to zero..

Table 2. Monthly regression equations used to compute the synthesized historic streamflow for the James River near Stratford, South Dakota

$\left[Q_{h-\text { sr }}\right.$ historic streamflow for the James River near Stratford, in acre-feet;

$Q_{h-a,}$ historic streamflow for the James River at Ashton, in acre-feet]

\begin{tabular}{lcc}
\hline Month & $\begin{array}{c}\text { Correlation } \\
\text { coeticlent }\end{array}$ & Regreesion equation \\
\hline January & 0.986 & $\ln Q_{h-s t r}=-0.500+0.941\left(\ln Q_{h-a}\right)$ \\
February & .958 & $\ln Q_{h-s t r}=-0.717+0.912\left(\ln Q_{h-a}\right)$ \\
March & .968 & $\ln Q_{h-s t r}=-0.641+0.998\left(\ln Q_{h-a}\right)$ \\
April & .990 & $\ln Q_{h-s t r}=-0.187+0.976\left(\ln Q_{h-a}\right)$ \\
May & .993 & $\ln Q_{h-s t r}=-0.220+1.01\left(\ln Q_{h-a}\right)$ \\
June & .989 & $\ln Q_{h-s t r}=-1.10+1.08\left(\ln Q_{h-a}\right)$ \\
July & .982 & $\ln Q_{h-s t r}=-0.608+1.05\left(\ln Q_{h-a}\right)$ \\
August & .966 & $\ln Q_{h-s t r}=-0.553+1.02\left(\ln Q_{h-a}\right)$ \\
September & .998 & $\ln Q_{h-s t r}=-0.184+0.985\left(\ln Q_{h-a}\right)$ \\
October & .988 & $\ln Q_{h-s t r}=-0.284+0.985\left(\ln Q_{h-a}\right)$ \\
November & .972 & $\ln Q_{h-s t r}=-0.690+1.02\left(\ln Q_{h-a}\right)$ \\
December & .987 & $\ln Q_{h-s t r}=-0.680+1.03\left(\ln Q_{h-a}\right)$ \\
\hline
\end{tabular}

James River near Redfield.--Historic streamflow record for the James River near Redfield (station 10 on pl. 1 and in table 1) is not available for October 1990 through December 1991. MOVE.1 was used to synthesize the historic streamflow. The James River at Ashton was used as the independent station because of its similar characteristics and close proximity to the James River near Redfield. Correlation of the monthly streamflows resulted in monthly correlation coefficients that ranged from 0.85 to 0.99 . 
Lames River near Mitchell.--Historic streamflow record for the James River near Mitchell (station 13 on pl. 1 and in table 1) is not available for January 1983 through December 1991.

Benson (1983) indicated that traveltime between the James River near Forestburg and the James River near Mitchell is about 3 days for a streamflow of about 900 cubic feet per second. Because there is a relatively short traveltime and no major tributary inflow between these stations, there is a good correlation coefficient of 0.995 for the untransformed concurrent streamflow values between these stations. Because of the strong correlation between the measured streamflow at the two stations, the streamflow for the James River near Mitchell was computed by using the streamflow for the James River near Forestburg as the independent variable in an OLS regression equation. Because the distribution of measured streamflows for the James River near Mitchell is skewed to the right, as indicated by a larger mean flow ( 313 cubic feet per second) than the median flow (71 cubic feet per second), a natural log transformation was used. The correlation coefficients and the regression equations used to compute the streamflow for the James River near Mitchell $\left(Q_{h-m}\right)$ by using the streamflow for the James River near Forestburg $\left(Q_{h-f}\right)$ are listed in table 3.

Table 3. Monthly regression equations used to compute the synthesized historic streamflow for the James River near Mitchell, South Dakota

$\left[Q_{h-m}\right.$, historic streamflow for the James River near Mitchell, in acre-feet; $Q_{h-f}$, historic streamflow for the James River near Forestburg, in acre-feet]

\begin{tabular}{lcc}
\hline Month & $\begin{array}{c}\text { Correlation } \\
\text { coefficlent }\end{array}$ & Regression oquation \\
\hline January & 0.995 & $\ln Q_{h-m}=0.877+0.908\left(\ln Q_{h-f}\right)$ \\
February & .992 & $\ln Q_{h-m}=1.69+0.806\left(\ln Q_{h-f}\right)$ \\
March & .947 & $\ln Q_{h-m}=0.533+0.966\left(\ln Q_{h-f}\right)$ \\
April & .999 & $\ln Q_{h-m}=0.286+0.988\left(\ln Q_{h-f}\right)$ \\
May & .998 & $\ln Q_{h-m}=0.557+0.955\left(\ln Q_{h-f}\right)$ \\
June & .967 & $\ln Q_{h-m}=0.228+0.990\left(\ln Q_{h-f}\right)$ \\
July & .979 & $\ln Q_{h-m}=-0.214+1.03\left(\ln Q_{h-f}\right)$ \\
August & .997 & $\ln Q_{h-m}=1.99+0.793\left(\ln Q_{h-f}\right)$ \\
September & .996 & $\ln Q_{h-m}=1.70+0.796\left(\ln Q_{h-f}\right)$ \\
October & .991 & $\ln Q_{h-m}=-0.194+1.04\left(\ln Q_{h-f}\right)$ \\
November & .991 & $\ln Q_{h-m}=2.26+0.712\left(\ln Q_{h-f}\right)$ \\
December & .987 & $\ln Q_{h-m}=1.94+0.764\left(\ln Q_{h-f}\right)$ \\
\hline
\end{tabular}

\section{SYNTHESIZED UNREGULATED STREAMFLOW RECORD COMPUTATION}

Synthesized unregulated streamflow, as used in this report, is defined as the monthly streamflow that would occur in the absence of the hydrologic effects caused by Jamestown Reservoir, Pipestem Reservoir, Sand Lake National Wildlife Refuge; consumptive surface-water withdrawals, such as irrigation, municipal use, and industrial use; and wastewater returns. The estimates of unregulated stream flow do not 
account for numerous small, low-head dams that have been built on the main stem and tributaries of the James River for water supply, fish and wildlife, and recreational purposes. These low-head dams are expected to have minimal effects on the monthly streamflow values.

Synthesized unregulated streamflow (supplement 2) was computed for 1983-91 for the same 15 James River gaging stations (p1. 1 and table 1) for which the historic streamflow data were compiled. The method used for each of these 15 stations is described in the following text. The same method that was used by Wiche, Benson, and Emerson (1989) is used whenever possible. Surface-water withdrawal and wastewater return data (supplement 3 ) that were used to compute synthesized unregulated streamflow were estimated from the U.S. Geological Survey's State Water Use Data System or were provided by municipalities.

James River near Grace City.--Synthesized unregulated streamflow for the James River near Grace City (station 1 on pl. 1 and in table 1) is about the same as the historic streamflow. Mean monthly surfacewater withdrawals between the headwaters of the James River and the James River near Grace City were less than 0.10 cubic foot per second during 1983-91. Unregulated streamflow for the James River near Grace City was computed by adding the estimated surface-water withdrawals upstream from the station to the historic streamflow at the station. The assumption was made that no part of the surface-water withdrawals returned to the James River.

James River above Arrowwood Lake near Kensal.--Synthesized unregulated streamflow for the James River above Arrowwood Lake near Kensal (station 2 on pl. 1 and in table 1) was computed in the same manner as the unregulated streamflow for the James River near Grace City. There are no surfacewater withdrawals between the James River near Grace City and the James River above Arrowwood Lake near Kensal. The unregulated streamflow for the James River above Arrowwood Lake near Kensal was set equal to the historic streamflow for the station plus the estimated surface-water withdrawals between the headwaters and the James River near Grace City.

James River near Pingree.--Synthesized unregulated streamflow for the James River near Pingree (station 3 on pl. 1 and in table 1) was computed in the same manner as the unregulated streamflow for the James River near Grace City. There are no surface-water withdrawals between the James River near Grace City and the James River near Pingree. The unregulated streamflow for the James River near Pingree was set equal to the historic streamflow at the station plus the estimated surface-water withdrawals between the headwaters and the James River near Grace City.

James River at Jamestown.--Synthesized unregulated streamflow for the James River at Jamestown (station 4 on pl. 1 and in table 1) was computed by removing the effects of Jamestown Reservoir and Pipestem Reservoir. Wiche, Benson, and Emerson (1989) used MOVE. 1 to compute unregulated streamflow for the James River at Jamestown for October 1968 through December 1982. The Sheyenne River at Cooperstown was used as the independent station. The same noncyclic (annual) regression equation ( $r=0.84$ ) that was used by Wiche, Benson, and Emerson (1989) was used to compute the unregulated streamflow for the James River at Jamestown for January 1983 through December 1991.

The water-balance procedure that was developed by Wiche, Benson, and Emerson (1989) was used as an altemative method to compute the unregulated streamflow for the James River at Jamestown for January 1983 through December 1991. Unregulated streamflow was computed by using the following equation:

$$
Q_{u-j}=Q_{h-j}+S+E A-P A-Q_{h-p s m}+Q_{u-p s m}+Q_{w-u}
$$


where $Q_{u-j}$ is unregulated streamflow for the James River at Jamestown, in acre-feet;

$Q_{h-j}$ is historic streamflow for the James River at Jamestown, in acre-feet;

$S$ is change in reservoir storage, in acre-feet;

$E$ is reservoir evaporation, in acre-feet;

$A$ is reservoir surface area, in acre-feet;

$P$ is precipitation falling on the reservoir, in acre-feet;

$Q_{h-p s m}$ is historic streamflow for Pipestem Creek at its junction with the James River, in acre-feet;

$Q_{u-p s m}$ is unregulated streamflow for Pipestem Creek at its junction. with the James River, in acre-feet; and

$Q_{w-n}$ is the surface-water withdrawal upstream of Jamestown Reservoir.

The historic streamflow for Pipestem Creek at its junction with the James River $\left(Q_{h-p s m}\right)$ was computed by multiplying the releases from Pipestem Dam by 1.04 to account for a 4-percent increase in the intervening drainage area between Pipestem Dam and the junction with the James River. The unregulated streamflow for Pipestem Creek at its junction with the James River $\left(Q_{u-p s m}\right)$ was computed by multiplying the unregulated streamflow for Pipestem Creek near Pingree by 1.59 to account for a 59-percent increase in the intervening contributing drainage area between the Pingree gage and the junction with the James River.

Unregulated streamflow computed by using MOVE.1 was compared to the unregulated streamflow computed by using water balance. Occasionally, considerable differences in the estimates of streamflow were found between the two methods. Wiche, Benson, and Emerson (1989) found similar differences and used examples to explain why some of the differences occur. Unregulated streamflow for the James River at Jamestown for January 1983 through December 1991 was computed by using MOVE.1, but adjustments were made to monthly stream flows where there was a large difference between the streamflow computed by using MOVE.1 and those computed by using water balance. The adjustments were made by comparing the monthly streamflow computed by using MOVE.1, water balance, and measured discharges upstream and downstream from the James River at Jamestown.

Lames River alt LaMoure.--Synthesized unregulated streamflow for the James River at LaMoure (station 5 on pl. 1 and in table 1) was computed by using the following equation:

$$
Q_{u-l a}=Q_{u-j}+\left(Q_{h-l a}-Q_{h-j}\right)+Q_{w-l a}
$$

where $Q_{u-l a}$ is unregulated streamflow for the James River at LaMoure,

$Q_{u-j}$ is unregulated streamflow for the James River at Jamestown,

$Q_{h-l a}$ is historic streamflow for the James River at LaMoure,

$Q_{h-j}$ is historic streamflow for the James River at Jamestown, and

$Q_{w-l a}$ is surface-water withdrawal between Jamestown and LaMoure.

The term $\left(Q_{h-l a}-Q_{h-j}\right)$ represents the historic increase or decrease in streamflow between the Jamestown and LaMoure stations. 
James River at North Dakota-South Dakota State line.--Synthesized unregulated streamflow for the James River at North Dakota-South Dakota State line (station 6 on pl. 1 and in table 1) for January 1983 through December 1991 was computed by using the following equations:

$$
\begin{aligned}
Q_{u-s t l}= & Q_{u-l a}+Q_{u-b r}+Q_{w-s t l} \text { if } Q_{u-l a}<100 \text { cubic feet per second; } \\
= & Q_{u-l a}+Q_{u-b r}+Q_{w-s t l}+Q_{u-l a}\left(-0.057+(5.70)\left(10^{-4}\right)\left(Q_{u-l a}\right)\right), \\
& \text { if } 100 \text { cubic feet per second } \leq Q_{u-l a} \leq 400 \text { cubic feet per } \\
& \text { second; and } \\
= & \left(Q_{u-l a}\right)(1.17)+Q_{u-b r}+Q_{w-s t l} \text { if } Q_{u-l a}>400 \text { cubic feet per } \\
& \text { second; }
\end{aligned}
$$

where $Q_{u-s t l}$ is unregulated streamflow for the James River at North Dakota-South Dakota State line,

$Q_{u-1 a}$ is unregulated streamflow for the James River at LaMoure,

$Q_{u-b r}$ is unregulated streamflow for Bear Creek near Oakes, and

$Q_{w-s t l}$ is surface-water withdrawal between LaMoure and North Dakota-South Dakota State line.

If the unregulated streamflow of the James River at LaMoure is less than 100 cubic feet per second, the unregulated streamflow of the James River at the State line is equal to the sum of the unregulated streamflow of the James River at LaMoure, the unregulated streamflow of Bear Creek, and the surfacewater withdrawal between LaMoure and North Dakota-South Dakota State line. When the unregulated streamflow at LaMoure is between 100 cubic feet per second and 400 cubic feet per second, the unregulated streamflow at the State line is equal to the sum of the unregulated streamflow at LaMoure; the unregulated streamflow of Bear Creek, the surface-water withdrawal between LaMoure and North DakotaSouth Dakota State line, and an additional amount that accounts for the intervening contributing drainage area between LaMoure and the State line. This additional contribution ranges from zero to 17 percent of the unregulated streamflow at LaMoure and is a linear function of the unregulated streamflow at LaMoure between 100 cubic feet per second and 400 cubic feet per second. For unregulated streamflows greater than $\mathbf{4 0 0}$ cubic feet per second, the additional contribution is 17 percent of unregulated streamflow of the James River at LaMoure. The 17-percent factor is based on the intervening contributing drainage area of the James River between LaMoure and the State line.

James River at Columbia.--Synthesized unregulated streamflow for the James River at Columbia (station 7 on pl. 1 and in table 1) was computed by applying the drainage-area ratio method to the unregulated streamflow for the James River at North Dakota-South Dakota State line. The drainage-area ratio method was used instead of a water-balance due to problems associated with computing gains and losses (Wiche, Benson, and Emerson, 1989). The drainage-area ratio between the two stations is 1.15. However, this ratio probably does not apply for the entire range of flows that occur on the James River. Assuming the basin characteristics between the James River at North Dakota-South Dakota State line and the James River at Columbia prior to development of Sand Lake National Wildlife Refuge were similar to basin characteristics of the James River downstream from Columbia, the river probably gains little water and may even lose water during low-flow conditions (Benson, 1983). Contributing drainage area of the James River between the two stations probably increases at the time of large runoff because depressional storage has been filled as a result of excess runoff. Because of these basin characteristics, a variable drainage-area ratio was developed to compute synthesized unregulated streamflow for the James River at Columbia. 
The 25-percent quartile (13.5 cubic feet per second) and the 75-percent quartile (74.2 cubic feet per second) statistics were computed for the unregulated streamflow for the James River at North DakotaSouth Dakota State line for the period January 1983 through December 1991. Analysis of streamflow records indicates that when streamflow for the James River at Columbia is less than 13.5 cubic feet per second, the contribution from the intervening drainage area between the two stations is minimal. When the streamflow is greater than 74.2 cubic feet per second, the intervening drainage area contributes runoff to the James River. Synthesized unregulated streamflow for the James River at Columbia was computed by using the following equations:

$$
\begin{aligned}
Q_{u-c}= & Q_{u-s t l}, \text { if } Q_{u-s t l}<13.5 \text { cubic feet per second; } \\
= & Q_{u-s t l}+Q_{u-s t l}\left(-0.0333+0.00247\left(Q_{u-s t l}\right)\right), \text { if } \\
& 13.5 \text { cubic feet per second } \leq Q_{u-s t l} \leq 74.2 \text { cubic } \\
& \text { feet per second; and } \\
= & Q_{u-s t l}(1.15), \text { if } Q_{u-s t l}>74.2 \text { cubic feet per second; }
\end{aligned}
$$

where $Q_{u-c}$ is unregulated streamflow for the James River at Columbia, and

$Q_{u-s t l}$ is unregulated streamflow for the James River at North Dakota-South Dakota State line.

In March 1989, the measured streamflow for the James River at Columbia was negative (reverse flow; supplement 1). Historic streamflow was set to zero for this month when computing the unregulated streamflow for downstream sites.

James River near Stratford.--Synthesized unregulated streamflow for the James River near Stratford (station 8 on pl. 1 and in table 1) was computed by using the following equation:

$$
Q_{k-s i r}=Q_{u-c}+\left(Q_{h-s i r}-Q_{h-c}\right)+M_{a}+Q_{w-s}-W_{a}
$$

where $Q_{u-s t r}$ is unregulated streamflow for the James River near Stratford,

$Q_{u-c}$ is unregulated streamflow for the James River at Columbia,

$Q_{h-s t r}$ is historic streamflow for the James River near Stratford,

$Q_{h-c}$ is historic streamflow for the James River at Columbia,

$M_{a}$ is municipal withdrawal by the city of Aberdeen,

$Q_{w-s}$ is irrigation withdrawal between Columbia and Stratford, and

$W_{a}$ is wastewater return by the city of Aberdeen.

Use of equation 10 resulted in negative unregulated streamflow for 9 months of the 9-year study.

However, inspection of the streamflow data revealed that the historic streamflow loss in the reach from

Columbia to Stratford exceeded the unregulated streamflow at Columbia. Reach

losses $\left(Q_{h-s t r}-Q_{h-c}\right)$ occur primarily in the spring when the main channel does not have the capacity to convey the snowmelt runoff. At this time, flow overtops the natural levee ridge and enters the overbanks. Much of the flow becomes trapped on the overbanks and is lost to evapotranspiration. Unregulated streamflow for these 9 months was set to zero.

James River at Ashton.--Synthesized unregulated streamflow for the James River at Ashton (station 9 and on pl. 1 and in table 1) was computed by using the following equation:

$$
Q_{u-a}=Q_{u-s i r}+\left(Q_{h-a}-Q_{h-s t r}\right)+Q_{w-a}
$$


where $Q_{u-a}$ is unregulated streamflow for the James River at Ashton,

$Q_{u-s t r}$ is unregulated streamflow for the James River near Stratford,

$Q_{h-a}$ is historic streamflow for the James River at Ashton,

$Q_{h-s t r}$ is historic streamflow for the James River near Stratford, and

$Q_{w-a}$ is irrigation withdrawal between Stratford and Ashton.

James River near Redfield.--Synthesized unregulated streamflow for the James River near Redfield (station 10 on pl. 1 and in table 1) was computed by using the following equation:

$$
Q_{u-r}=Q_{u-a}+\left(Q_{h-r}-Q_{h-a}\right)+Q_{w-r}
$$

where $Q_{u-r}$ is unregulated streamflow for the James River near Redfield,

$Q_{u-a}$ is unregulated streamflow for the James River at Ashton,

$Q_{h-r}$ is historic streamflow for the James River near Redfield,

$Q_{h-a}$ is historic streamflow for the James River at Ashton, and

$Q_{w-r}$ is irrigation withdrawal between Ashton and Redfield.

James River at Huron.--Synthesized unregulated streamflow for the James River at Huron (station 11 on pl. 1 and in table 1) was computed by using the following equation:

$$
Q_{u-h}=Q_{u-r}+\left(Q_{h-h}-Q_{h-r}\right)+M_{h}+Q_{w-h}
$$

where $Q_{u-h}$ is unregulated streamflow for the James River at Huron,

$Q_{u-r}$ is unregulated streamflow for the James River near Redfield

$Q_{h-h}$ is historic streamflow for the James River at Huron,

$Q_{h-r}$ is historic streamflow for the James River near Redfield,

$M_{h}$ is municipal withdrawal by the city of Huron, and

$Q_{w-h}$ is irrigation withdrawal between Redfield and Huron.

James River near Forestburg.--Synthesized unregulated monthly streamflow for the James River near Forestburg (station 12 on pl. 1 and in table 1) was computed by using the following equation:

$$
Q_{u-f}=Q_{u-h}+\left(Q_{h-f}-Q_{h-h}\right)+Q_{w-f}-W_{h}
$$

where $Q_{u-f}$ is unregulated streamflow for the James River near Forestburg,

$Q_{u-h}$ is unregulated streamflow for the James River at Huron,

$Q_{h-f}$ is historic streamflow for the James River near Forestburg,

$Q_{h-h}$ is historic streamflow for the James River at Huron,

$Q_{w-f}$ is irrigation withdrawal between Huron and Forestburg, and

$W_{h}$ is wastewater retum by the city of Huron.

James River near Mitchell.--Synthesized unregulated streamflow for the James River near Mitchell (station 13 on pl. 1 and in table 1) was computed by using the following equation:

$$
Q_{u-m}=Q_{u-f}+\left(Q_{h-m}-Q_{h-f}\right)+M_{m}+Q_{w-m}-W_{m}
$$


where $Q_{u-m}$ is unregulated streamflow for the James River near Mitchell,

$Q_{u-f}$ is unregulated streamflow for the James River near Forestburg,

$\boldsymbol{Q}_{h-m}$ is historic streamflow for the James River near Mitchell,

$Q_{h-f}$ is historic streamflow for the James River near Forestburg,

$M_{m}$ is municipal withdrawal from the James River to Lake Mitchell,

$Q_{w-m}$ is irrigation withdrawal between Forestburg and Mitchell, and

$W_{m}$ is wastewater retum by the city of Mitchell.

A negative unregulated streamflow for the James River near Mitchell occurred during 1 month.

Streamflow was set to zero for this month. The city of Mitchell withdraws water from the James River and stores the water in Lake Mitchell, which is located on Firesteel Creek. Irrigation withdrawals from rivers and streams draining into Lake Mitchell were included in $Q_{w-m}$ although they could have been excluded during months when Lake Mitchell was not discharging into the James River. Municipal withdrawals from Lake Mitchell were not included in $\boldsymbol{M}_{\boldsymbol{m}}$.

James River near Scotland.--Synthesized unregulated streamflow for the James River near Scotland (station 14 on pl. 1 and in table 1) was computed by using the following equation:

$$
Q_{u-s c}=Q_{u-m}+\left(Q_{h-s c}-Q_{h-m}\right)+Q_{w-s c}
$$

where $Q_{u-s c}$ is unregulated streamflow for the James River near Scotland,

$Q_{u-m}$ is unregulated streamflow for the James River near Mitchell,

$Q_{h-s c}$ is historic streamflow for the James River near Scotland,

$\boldsymbol{Q}_{h-m}$ is historic streamflow for the James River near Mitchell, and

$Q_{w-s c}$ is irrigation withdrawal between Mitchell and Scotland.

James River near Yankton.--Synthesized unregulated streamflow for the James River near Yankton (station 15 on pl. 1 and in table 1) was computed by using the following equation:

$$
Q_{u-y}=Q_{u-s c}+\left(Q_{h-y}-Q_{h-s c}\right)+Q_{w-y}
$$

where $\boldsymbol{Q}_{u-y}$ is unregulated streamflow for the James River near Yankton, .

$Q_{u-s c}$ is unregulated streamflow for the James River near Scotland,

$Q_{h-y}$ is historic streamflow near Yankton,

$Q_{h-s c}$ is historic streamflow for the James River near Scotland, and

$Q_{w-y}$ is irrigation withdrawal between Scotland and Yankton.

\section{SUMMARY}

Historic streamflow data were compiled and record extension methods were used, where necessary, to develop monthly streamflow records for January 1983 through December 1991 for 15 James River gaging stations in North Dakota and South Dakota. Five of the gaging stations were not in operation for part or all of 1983-91. Record extension methods were used to compute the synthesized historic streamflow for these five stations. The drainage-area ratio method was used to compute the historic streamflow for the James River above Arrowwood Lake near Kensal for January 1983 through September 1985 and the James River near Pingree for January 1983 through December 1991. Ordinary Least Squares (OLS) regression was used to compute the historic streamflow for the James River near Stratford for January 1983 through December 1991. Maintenance of Variance Extension Type 1 (MOVE.1) was used to compute the historic streamflow for the James River near Redfield for October 1990 through December 1991. OLS regression was used to compute the historic streamflow for the James River near Mitchell for January 1983 through December 1991. 
Synthesized unregulated streamflow was computed by removing the effects of Jamestown Reservoir, Pipestem Reservoir, Sand Lake National Wildlife Refuge; consumptive surface-water withdrawals, such as irrigation, municipal use, and industrial use; and wastewater returns. Synthesized unregulated streamflow was computed for 1983-91 for the same 15 James River gaging stations for which the historic streamflow was compiled. Unregulated streamflow for the James River near Grace City, James River above Arrowwood Lake near Kensal, and James River near Pingree (all stations are upstream of Jamestown Reservoir) is equal to the historic streamflow plus minor surface-water withdrawals from the James River. Synthesized unregulated streamflow for the James River at Jamestown was computed by using MOVE.1 and a water-balance procedure. Adjustments were made to monthly streamflows when large differences between the streamflow computed by using MOVE.1 and water balance occurred. Synthesized unregulated streamflow for the James River at LaMoure was computed by subtracting the historic stream flow for the James River at Jamestown from the historic streamflow at LaMoure, adding the surfacewater withdrawals between the two stations, and adding the unregulated streamflow for the James River at Jamestown. Synthesized unregulated streamflow for the James River at North Dakota-South Dakota State line was computed by summing the unregulated streamflow for the James River at LaMoure, the unregulated streamflow for Bear Creek near Oakes, the surface-water withdrawals from the James River between LaMoure and the State line, and the streamflow from the intervening contributing drainage area between LaMoure and the State line. The streamflow from the intervening contributing drainage area was computed as a function of the streamflow for the James River at LaMoure.

Synthesized unregulated streamflow for the James River at Columbia was computed by multiplying the unregulated streamflow for the James River at North Dakota-South Dakota State line by a varying drainage-area ratio. Synthesized unregulated streamflow for the James River at all stations downstream of the James River at Columbia was computed by subtracting the historic stream flow for the nearest upstream station from the historic streamflow for the station of interest, adding the unregulated streamflow for the nearest upstream station, adding the surface-water withdrawals between the two stations, and subtracting any wastewater returns. 


\section{REFERENCES}

Alley, W.M., and Burns, A.W., 1983, Mixed-station extension of monthly streamflow records: Journal of Hydraulic Engineering, v. 109, no. 10, p. 1272-1284.

Benson, R.D., 1983, A preliminary assessment of the hydrologic characteristics of the James River in South Dakota: U.S. Geological Survey Water-Resources Investigations Report 83-4077, p. 115.

Hirsch, R.M., 1979, An evaluation of some record reconstruction techniques: Water Resources Research, v. 15, no. 6, p. 1781-1790.

1982, A comparison of four streamflow record extension techniques: Water Resources Research, v. 18, no. 4, p. 1081-1088.

Matalas, N.C., and Jacobs, B.A., 1964, A correlation procedure for augmenting hydrologic data: U.S. Geological Survey Professional Paper 434-E, 7 p.

Stedinger, J.R., 1980, Fitting log normal distribution to hydrologic data: Water Resources Research, v. 16, no. 3, p. 481-490.

Thomas, D.M., and Benson, M.A., 1970, Generalization of streamflow characteristics from drainage-basin characteristics: U.S. Geological Survey Water-Supply Paper 1975, 55 p.

U.S. Department of the Interior, 1983, Final supplemental environmental statement, Garrison Diversion Unit, Pick Sloan Missouri Basin Program, North Dakota: U.S. Bureau of Reclamation, Bismarck, North Dakota, [variously paged].

Wiche, G.J., Benson, R.D., and Emerson, D.G., 1989, Streamflow at selected gaging stations on the James River in North Dakota and South Dakota, 1953-82, with a section on climatology: U.S. Geological Survey WaterResources Investigations Report 89-4039,99 p. 


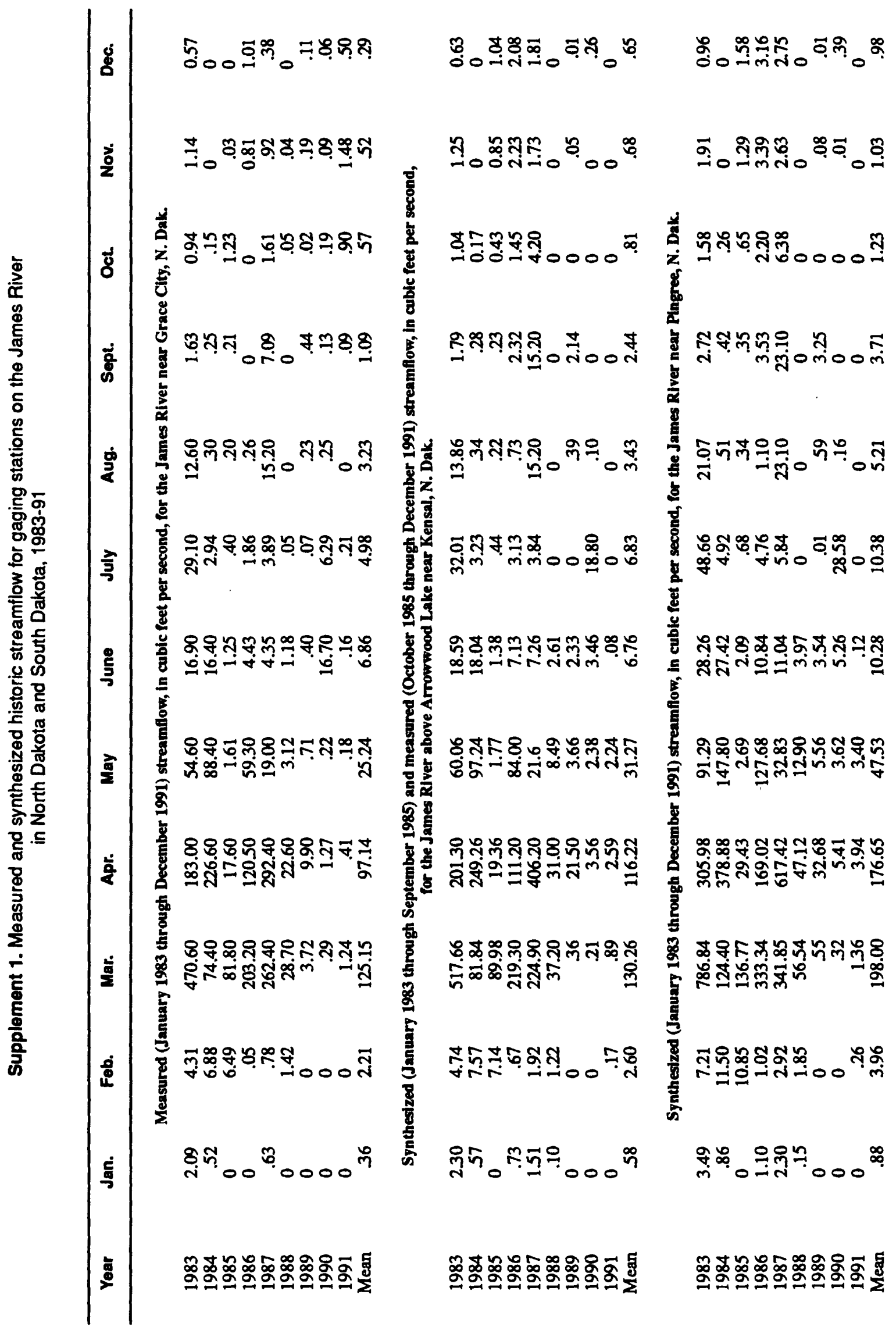




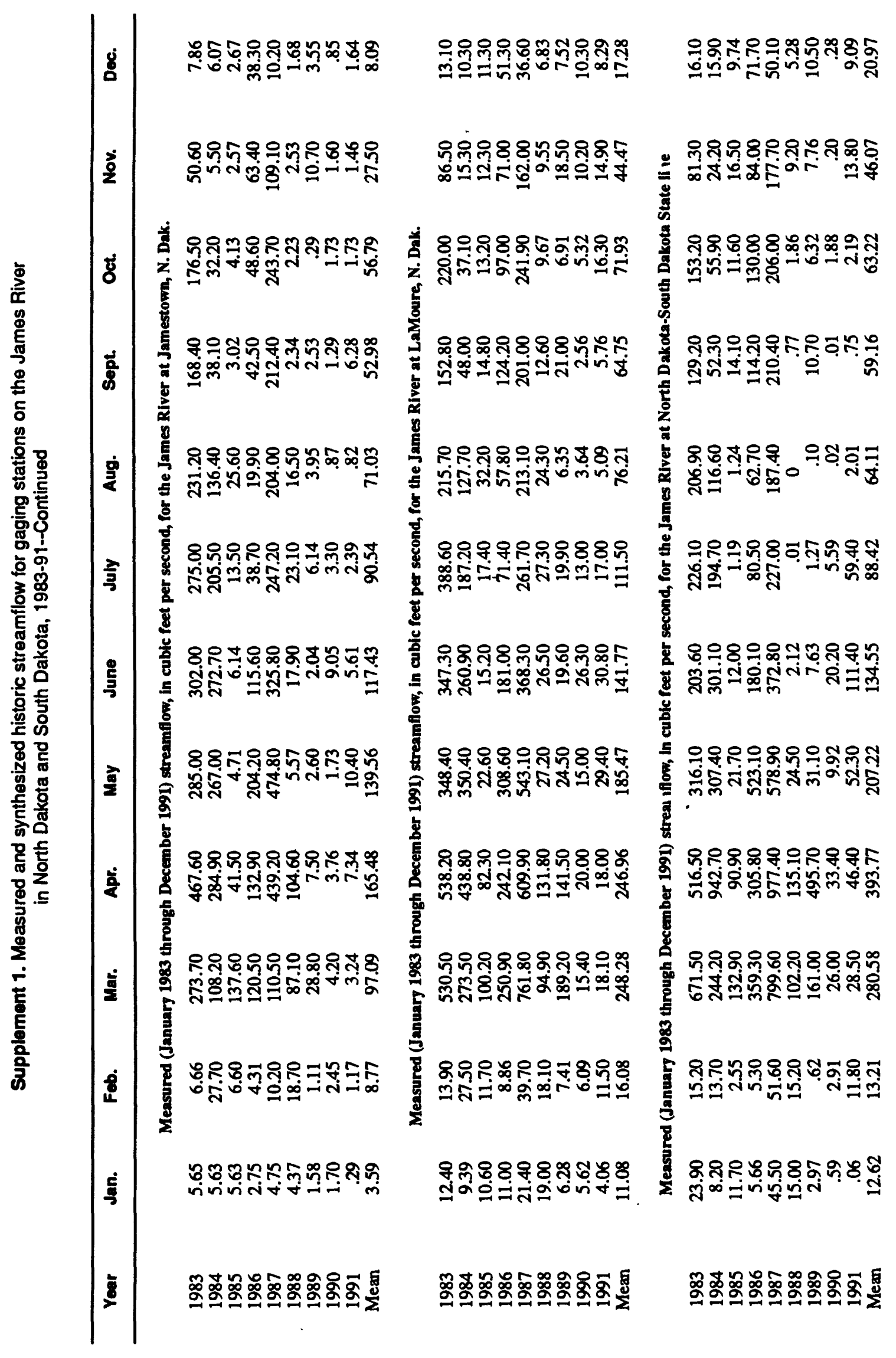




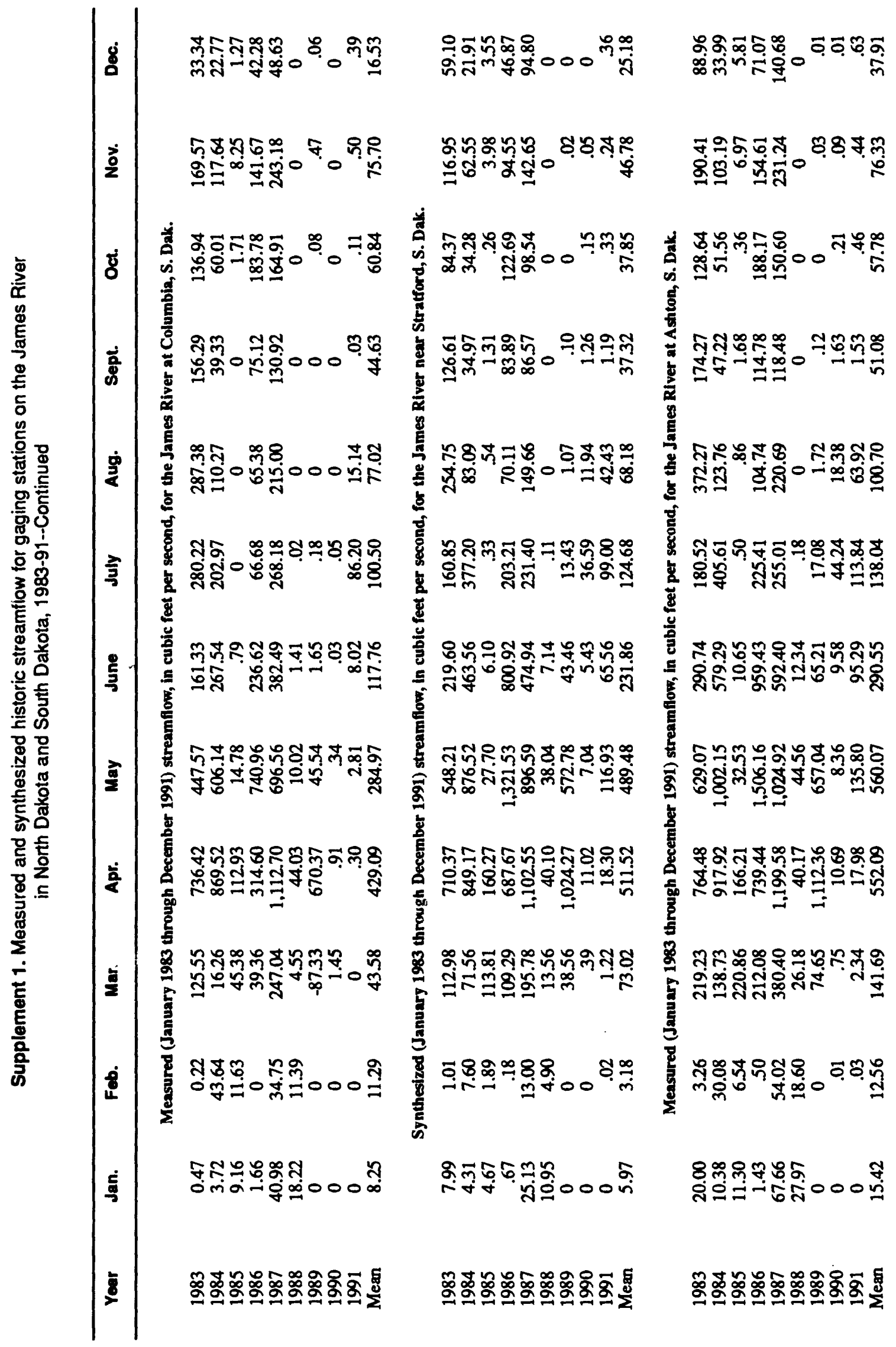




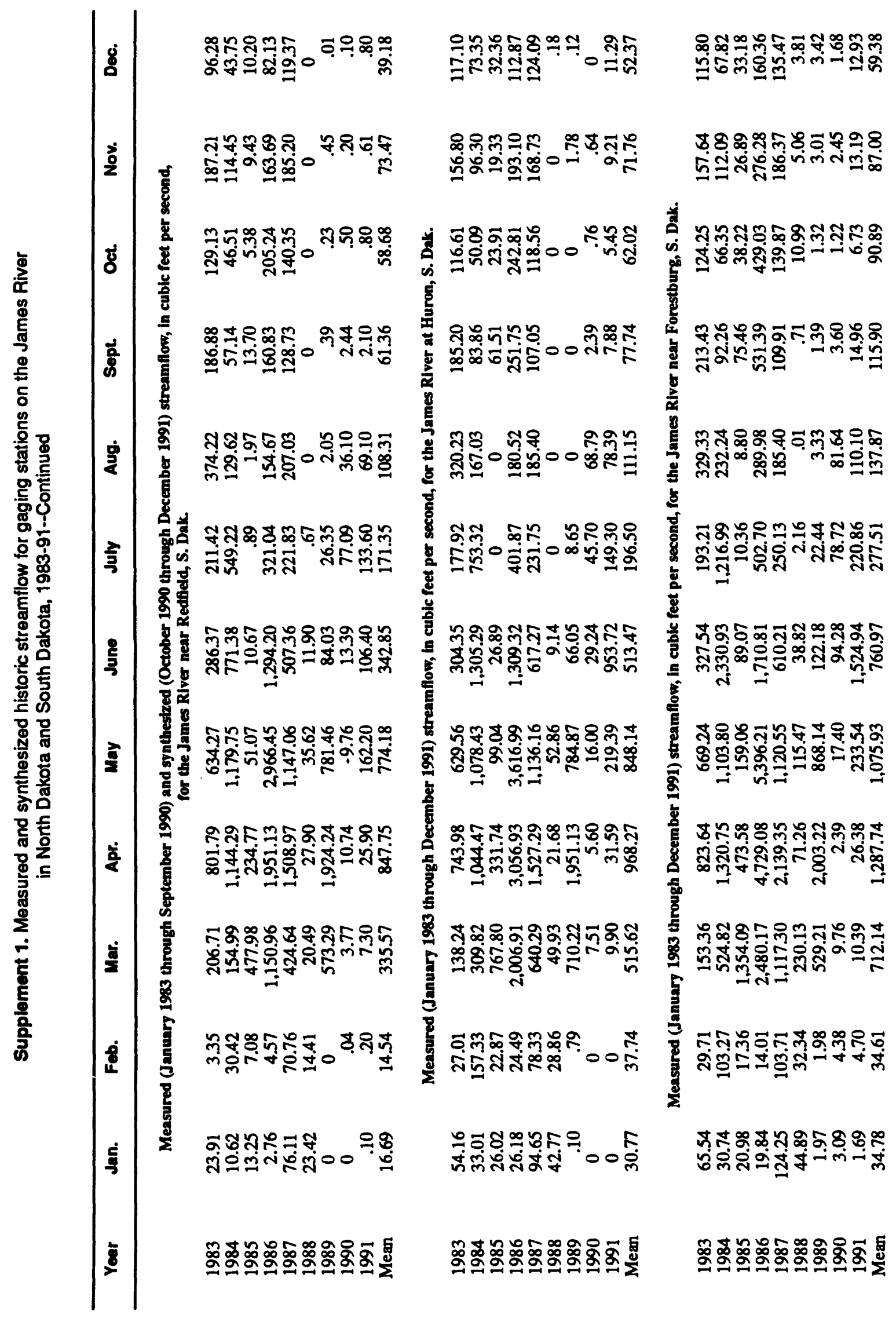




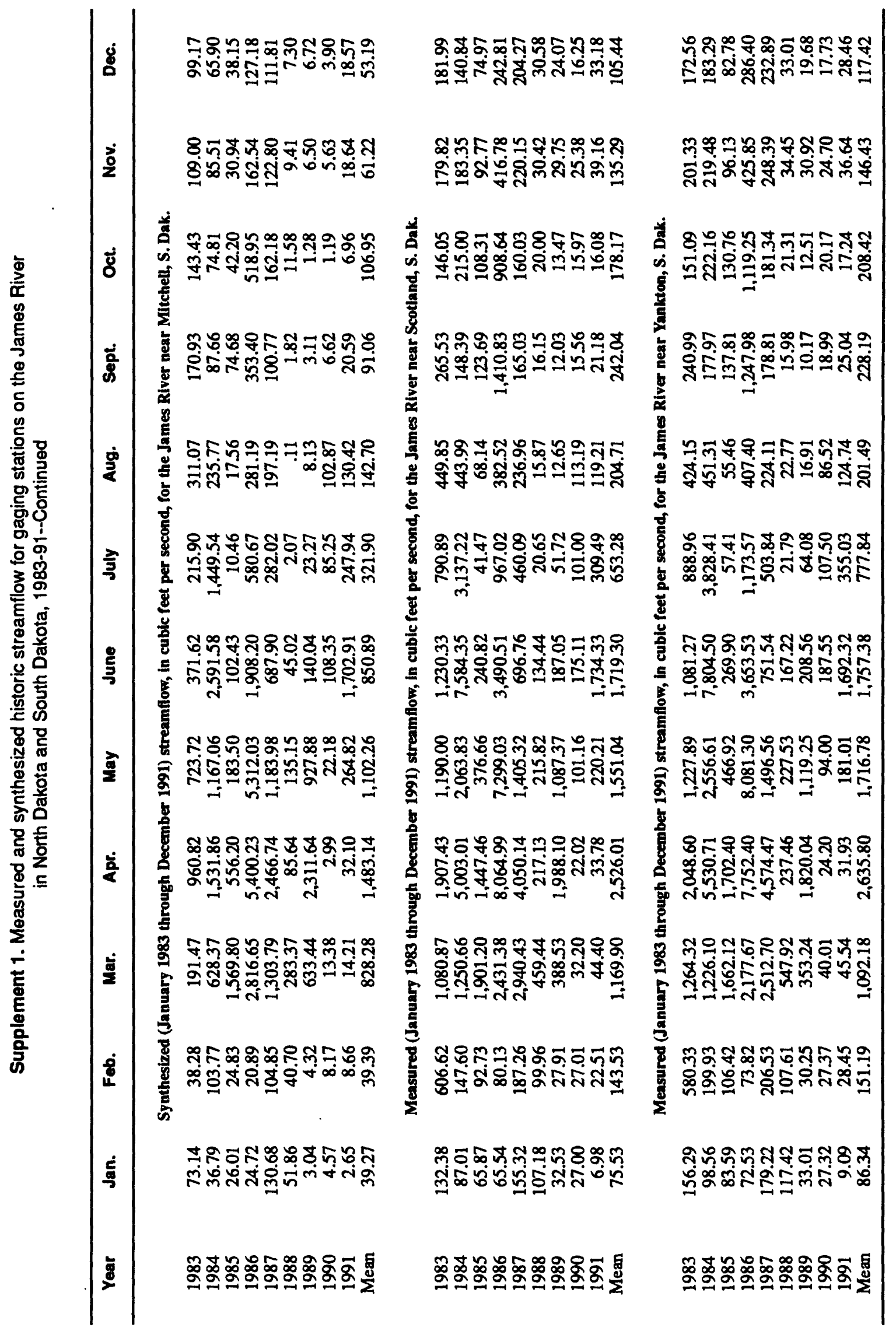




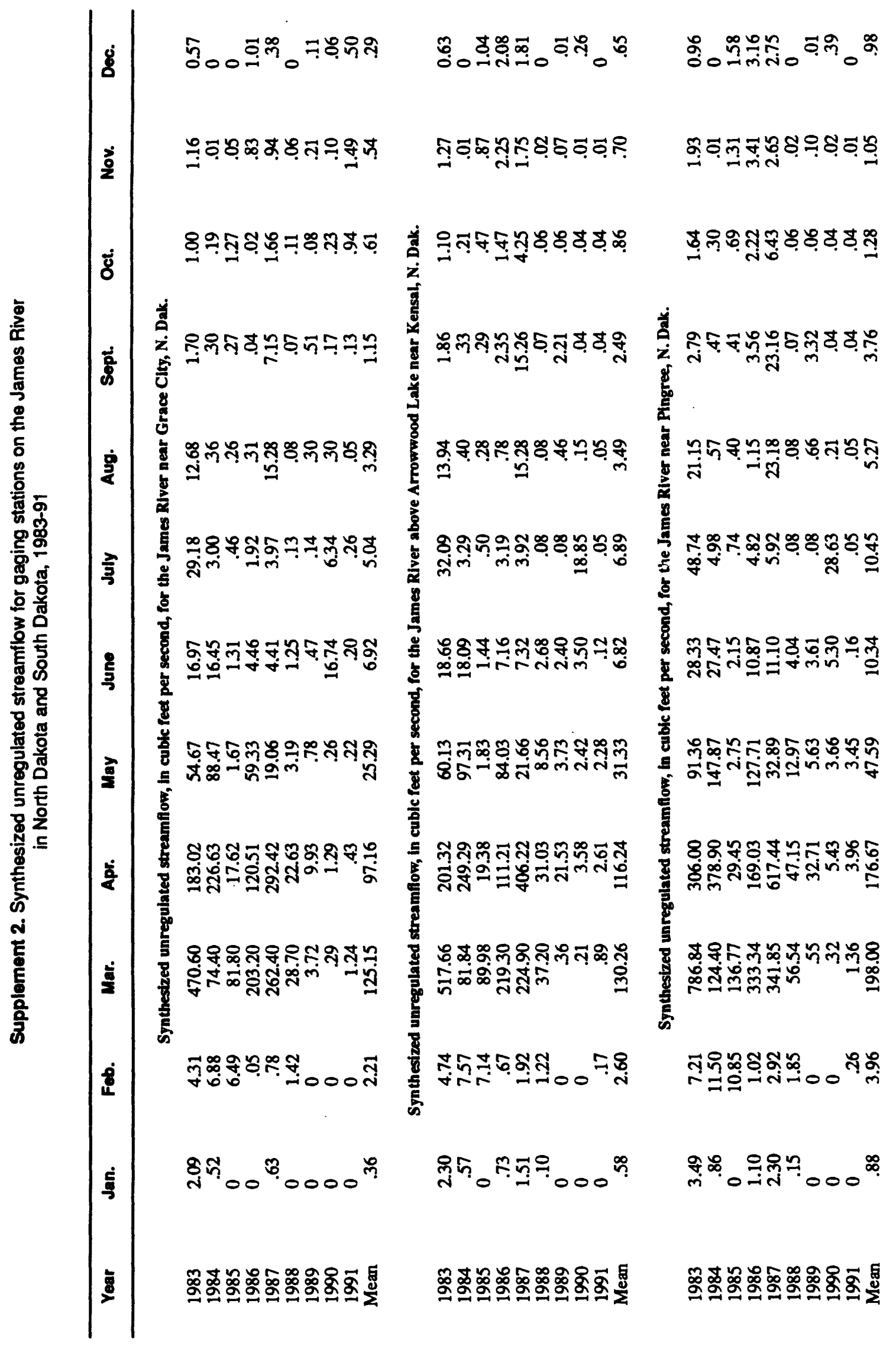




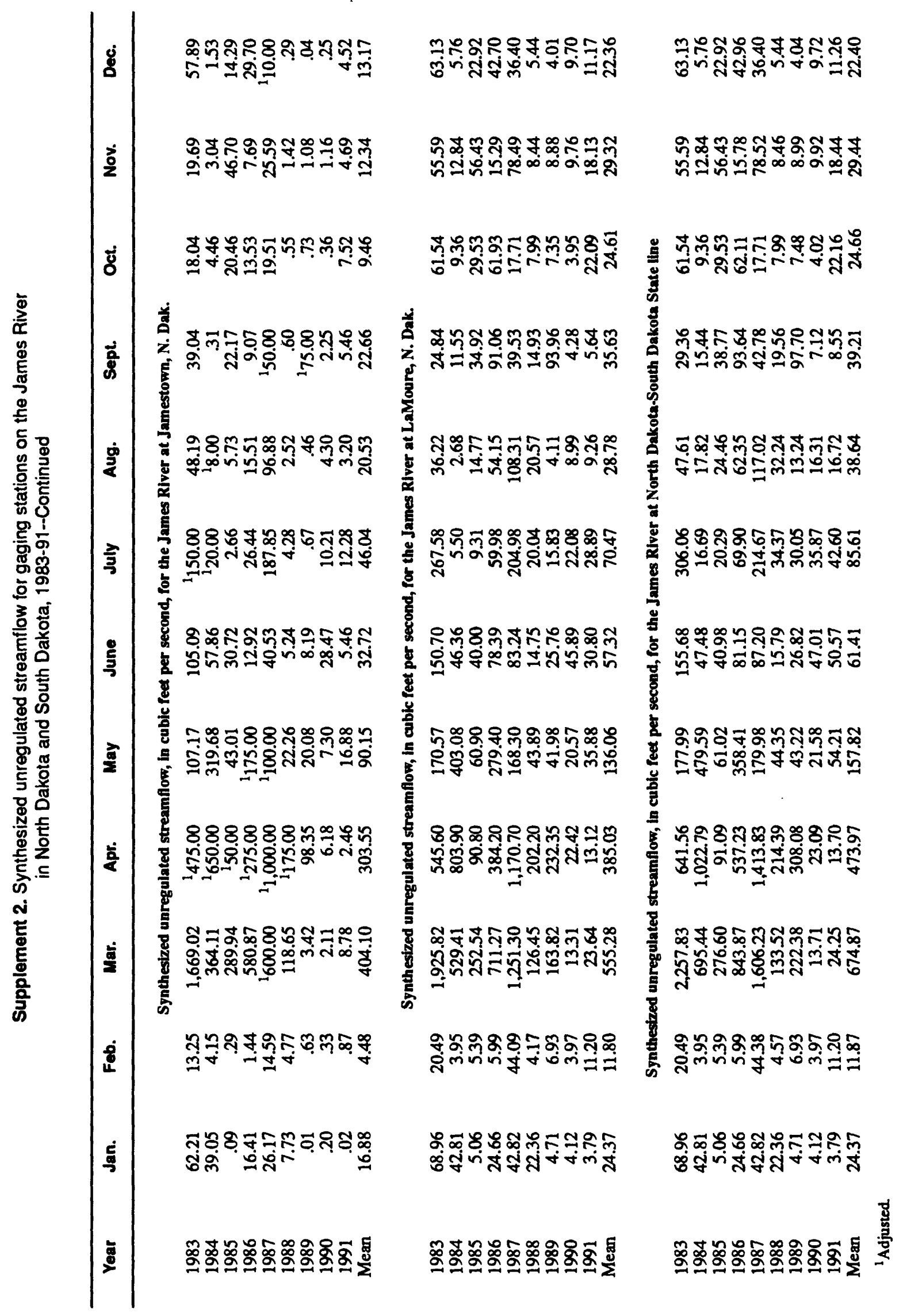




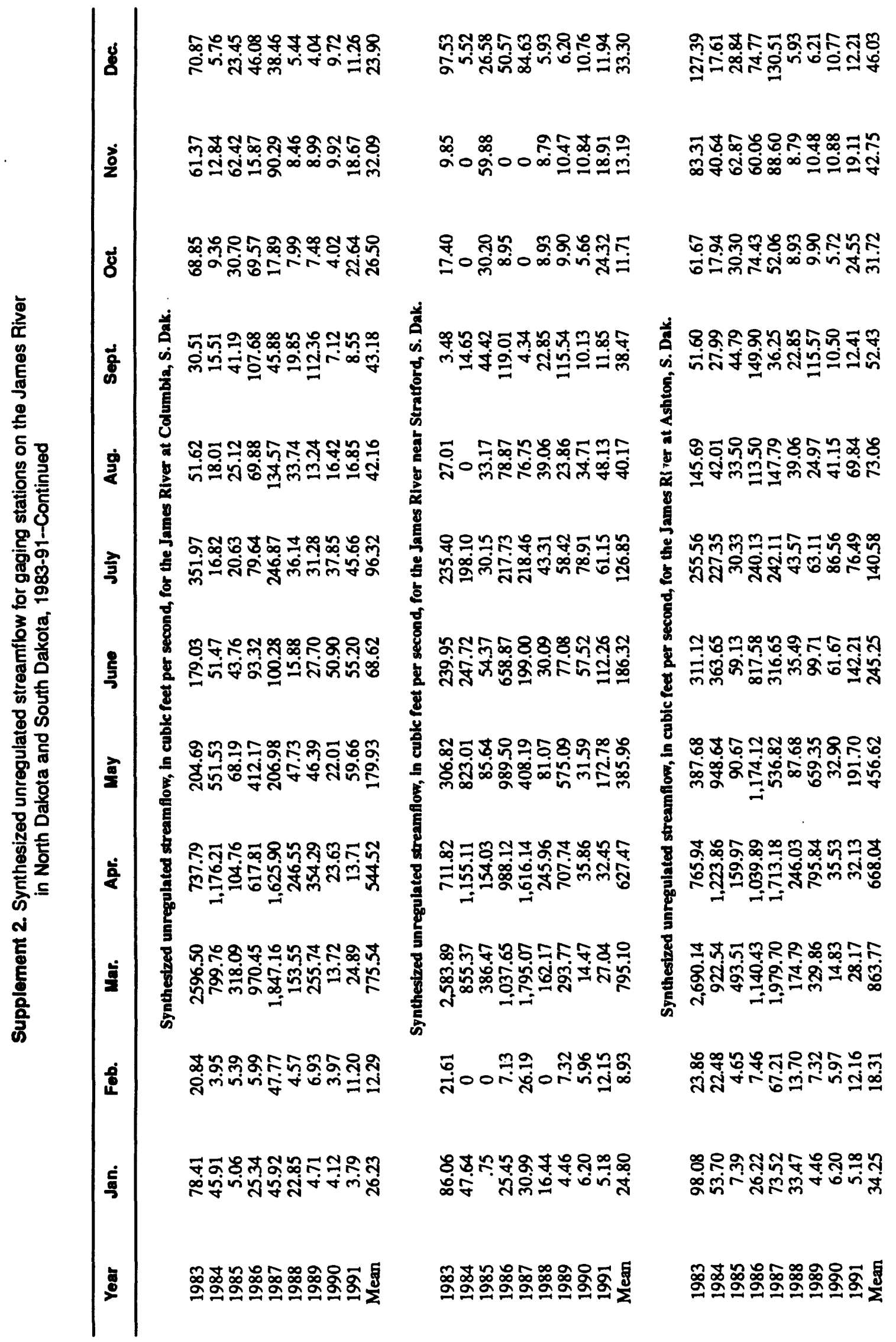




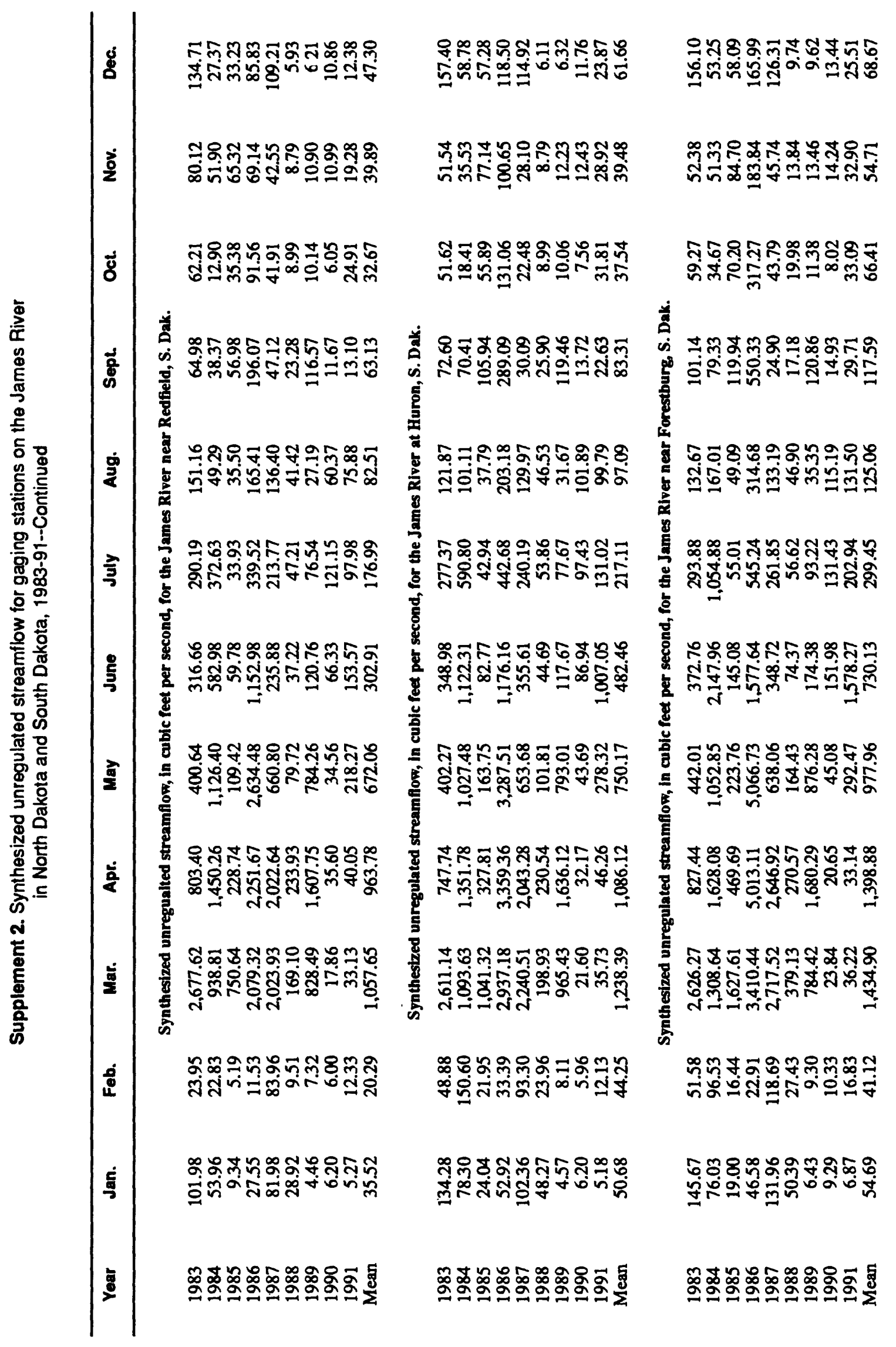




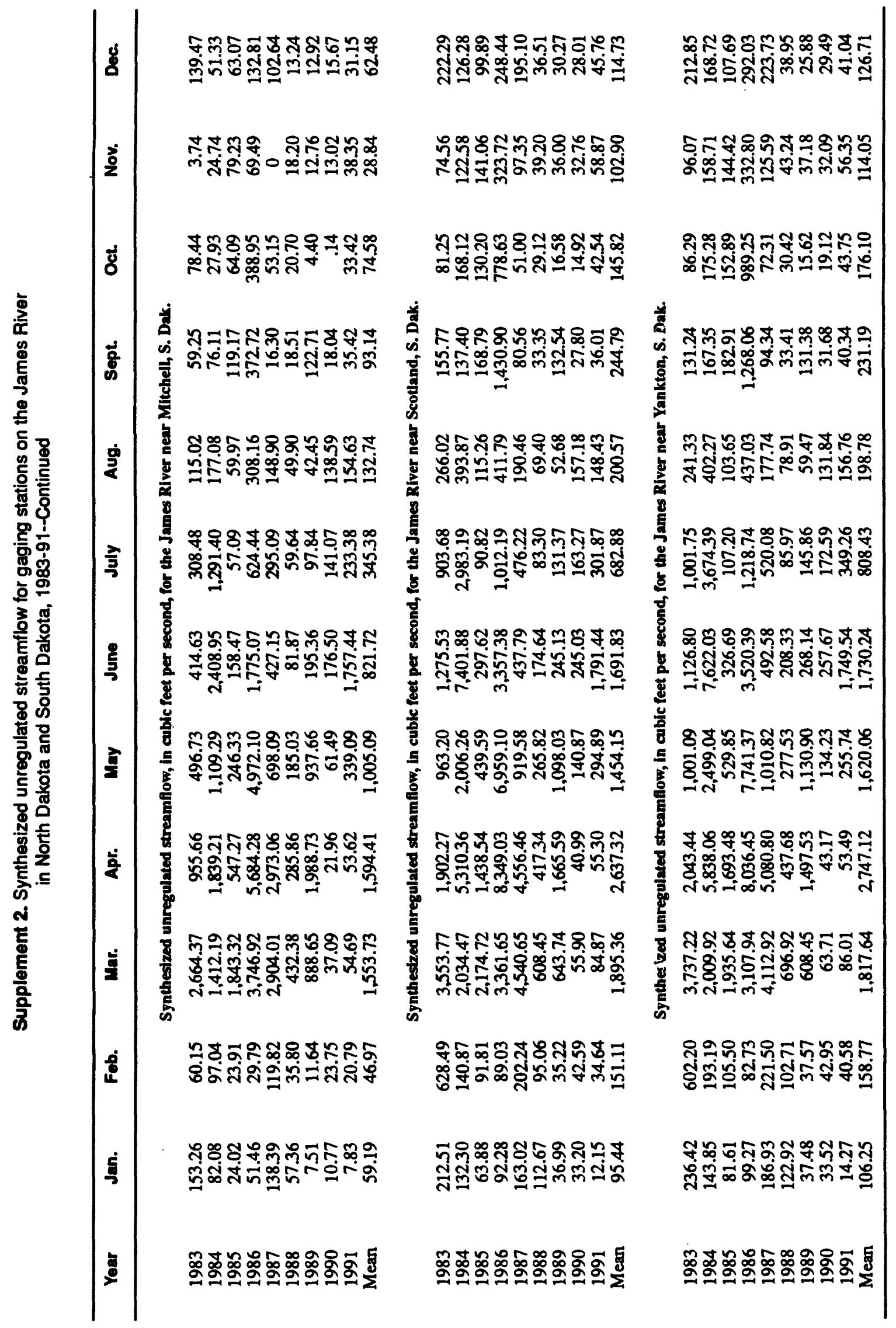




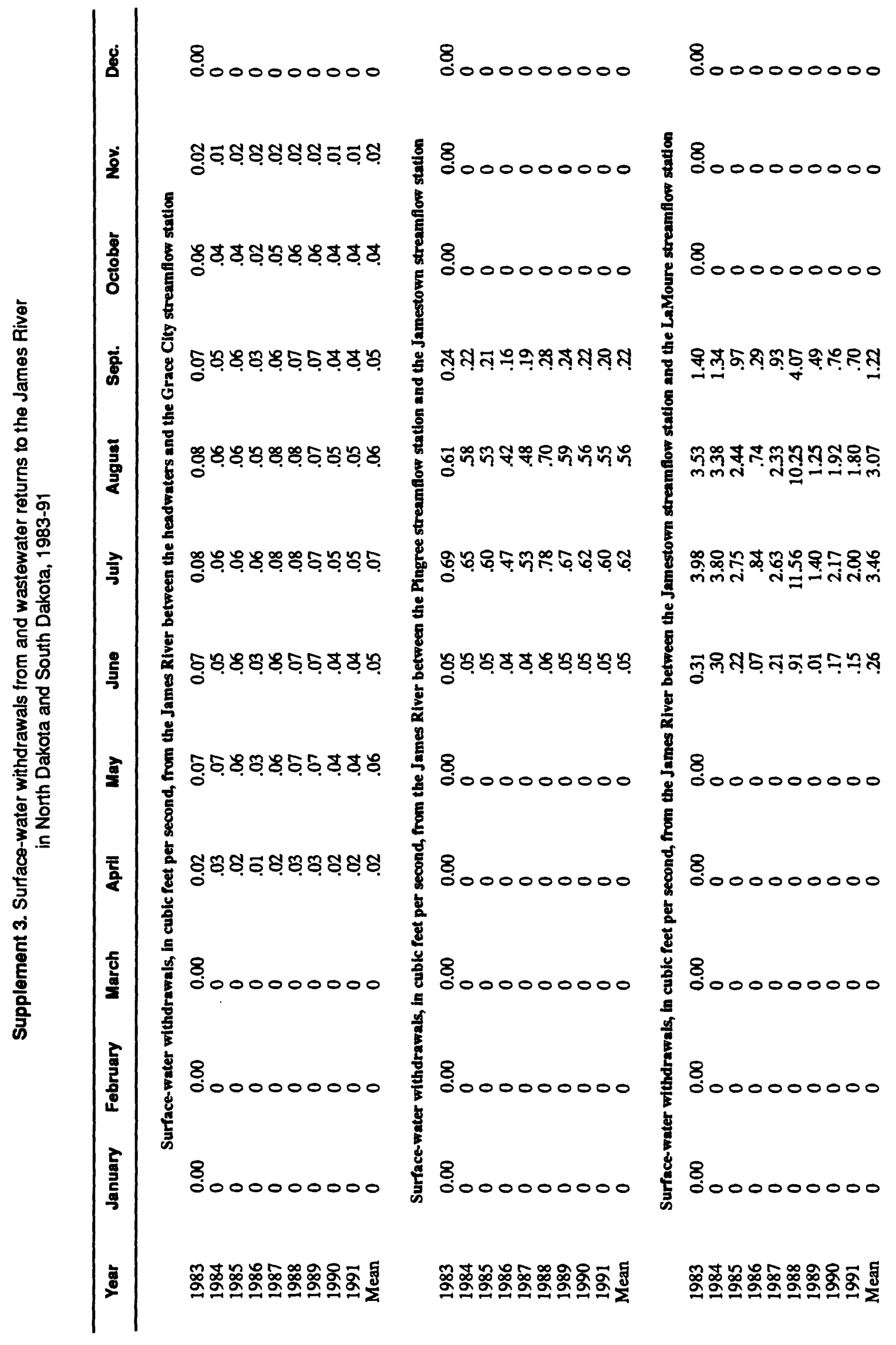




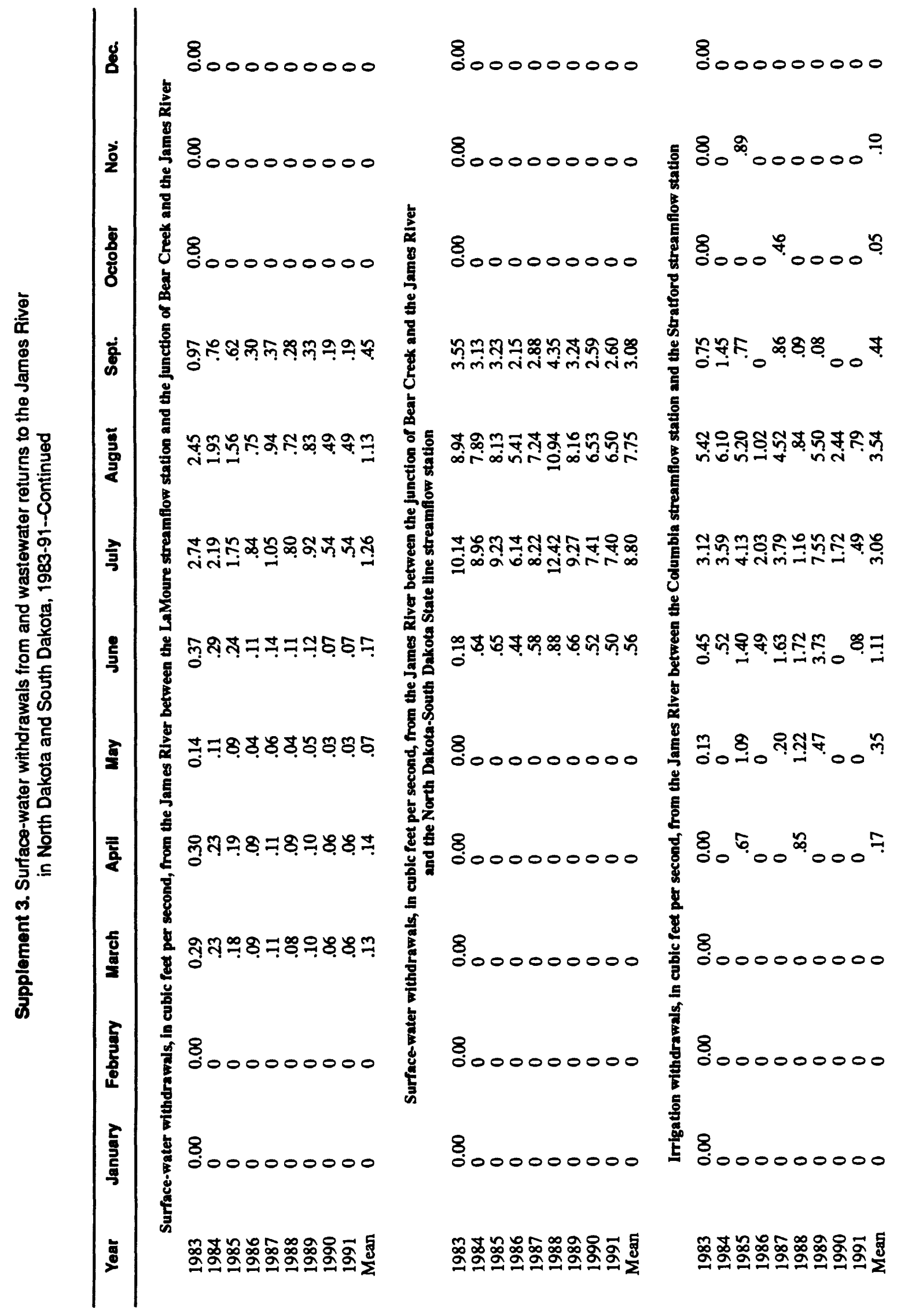




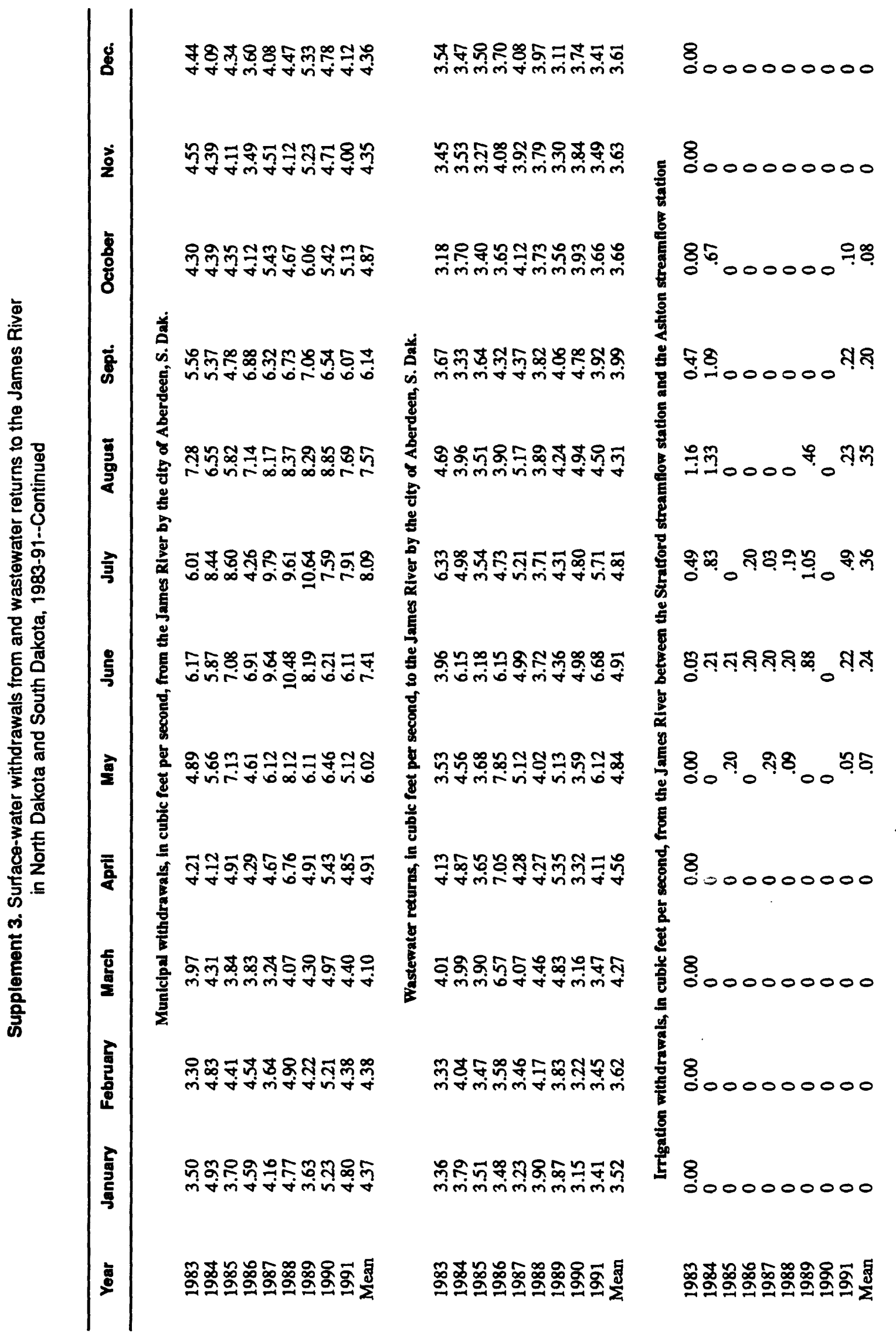




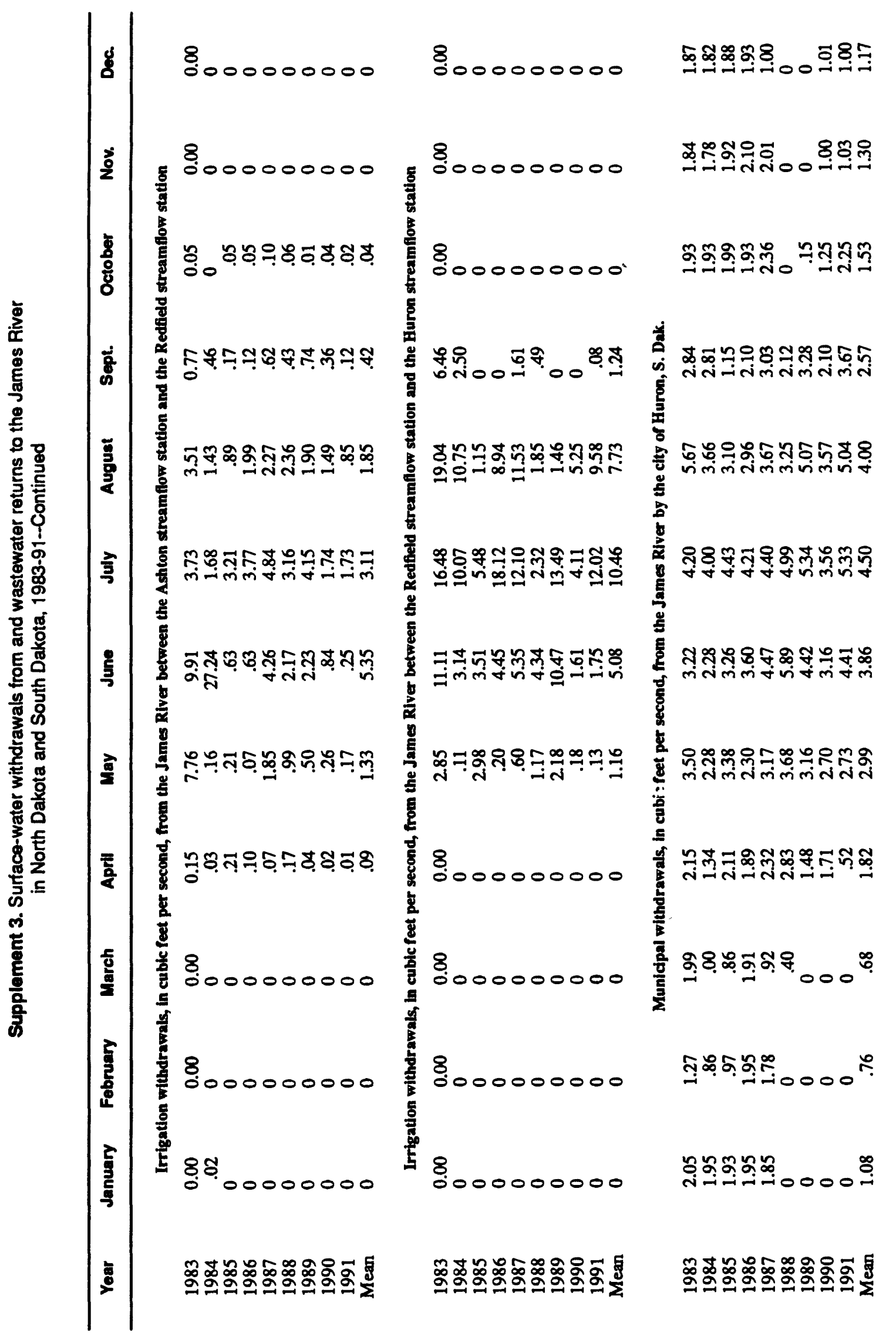




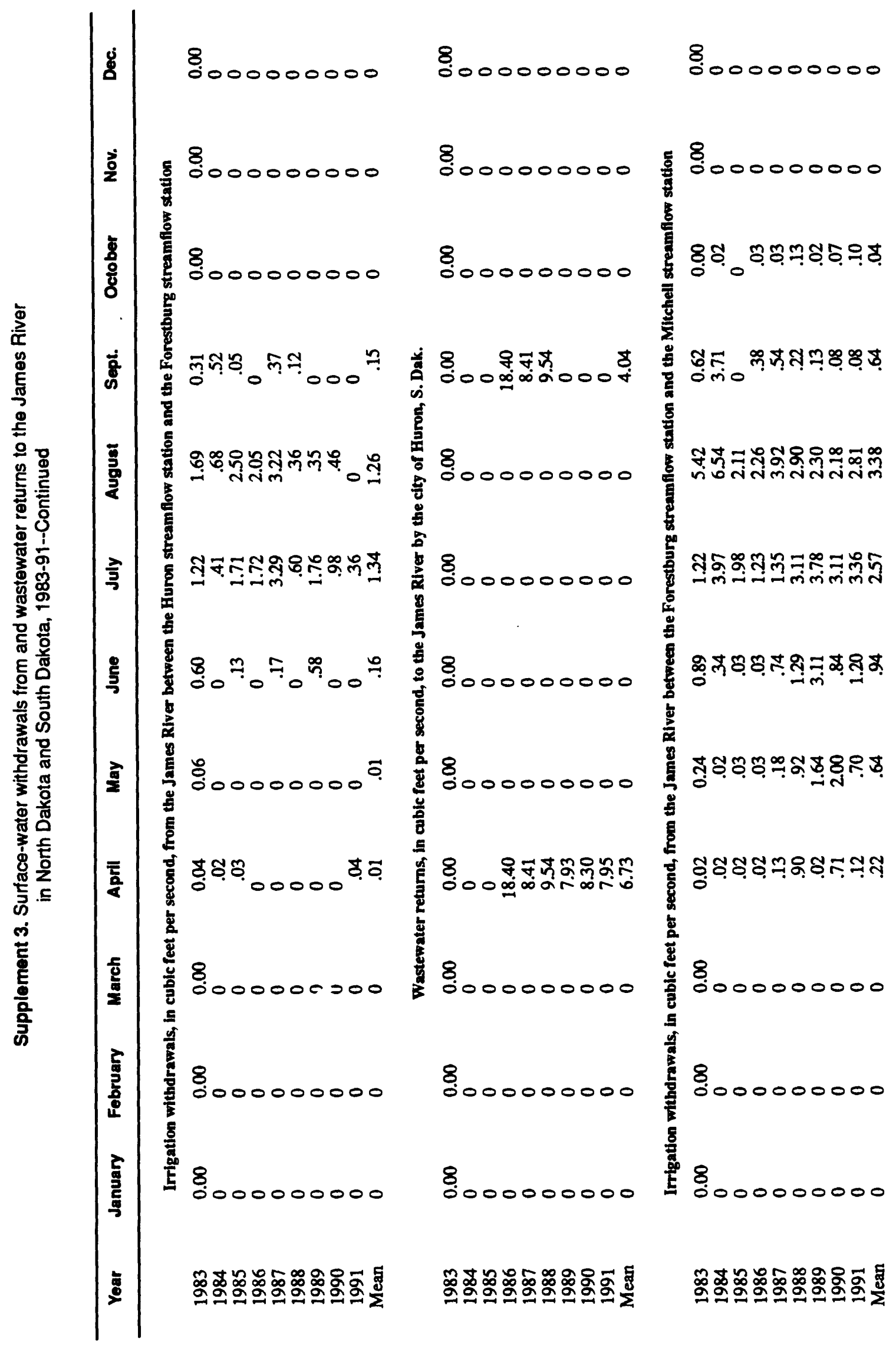




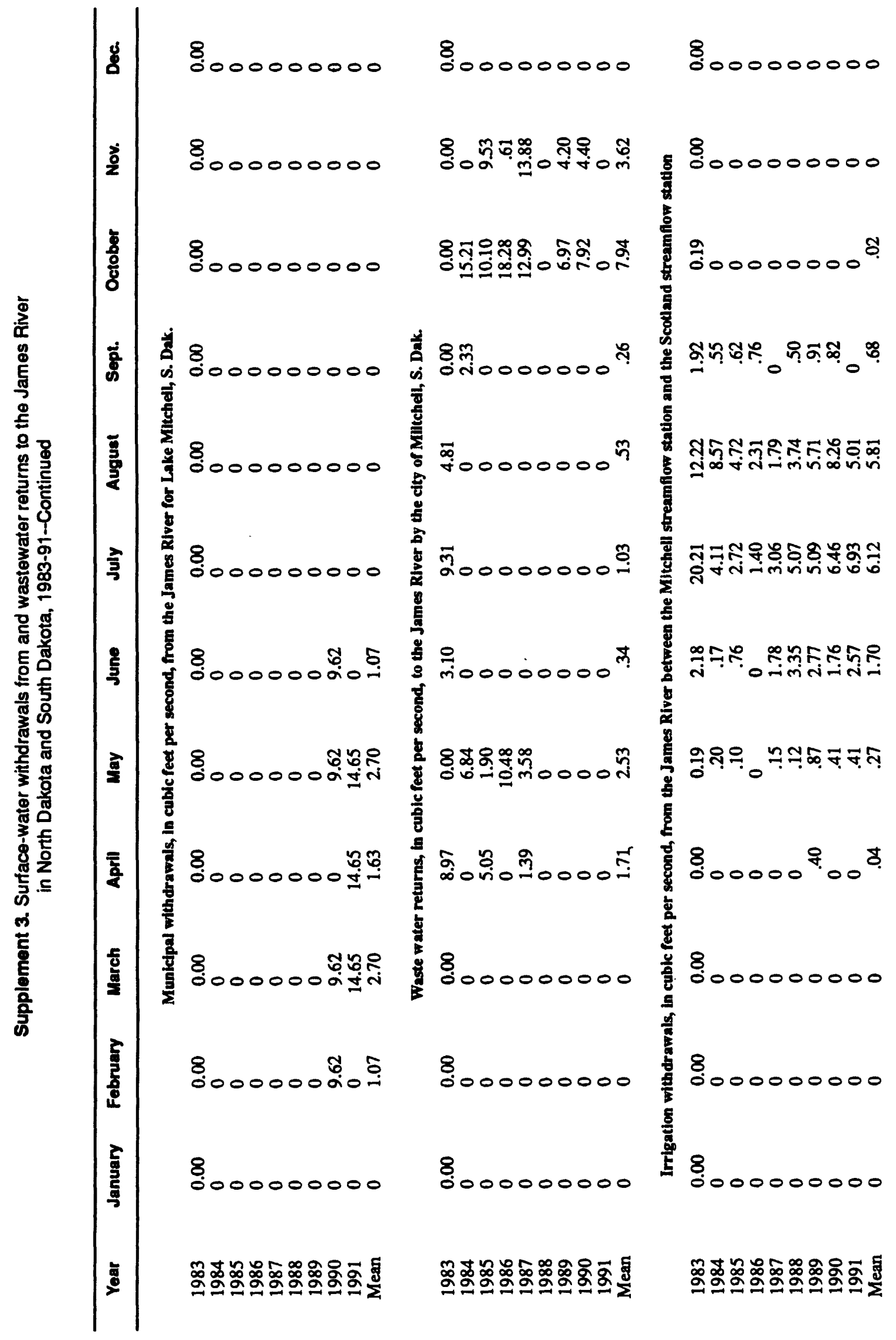




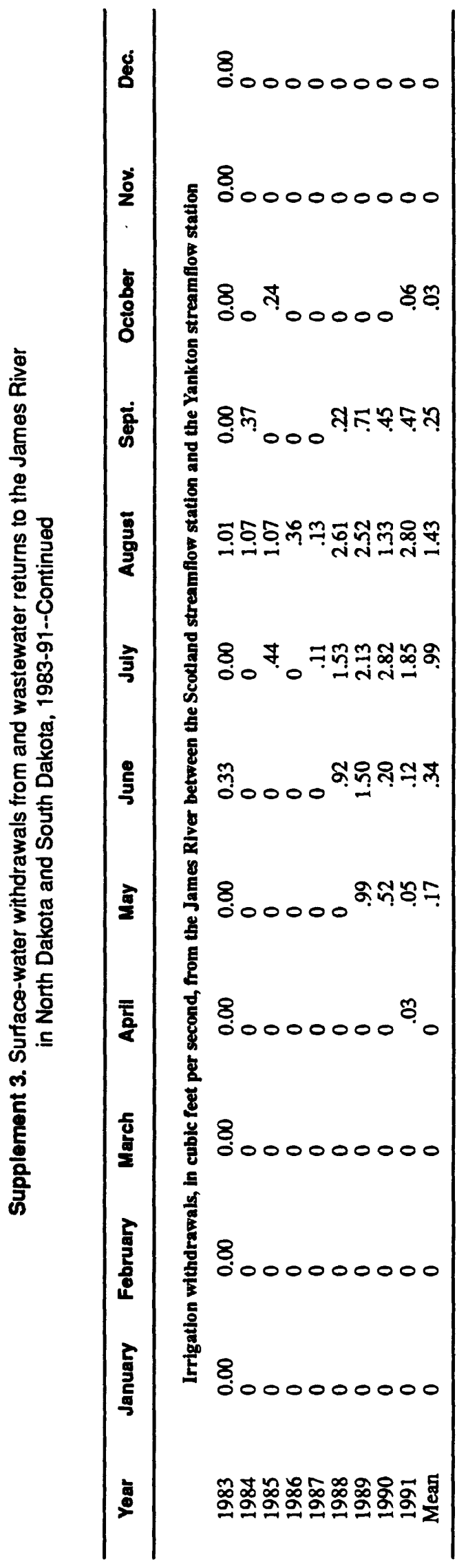




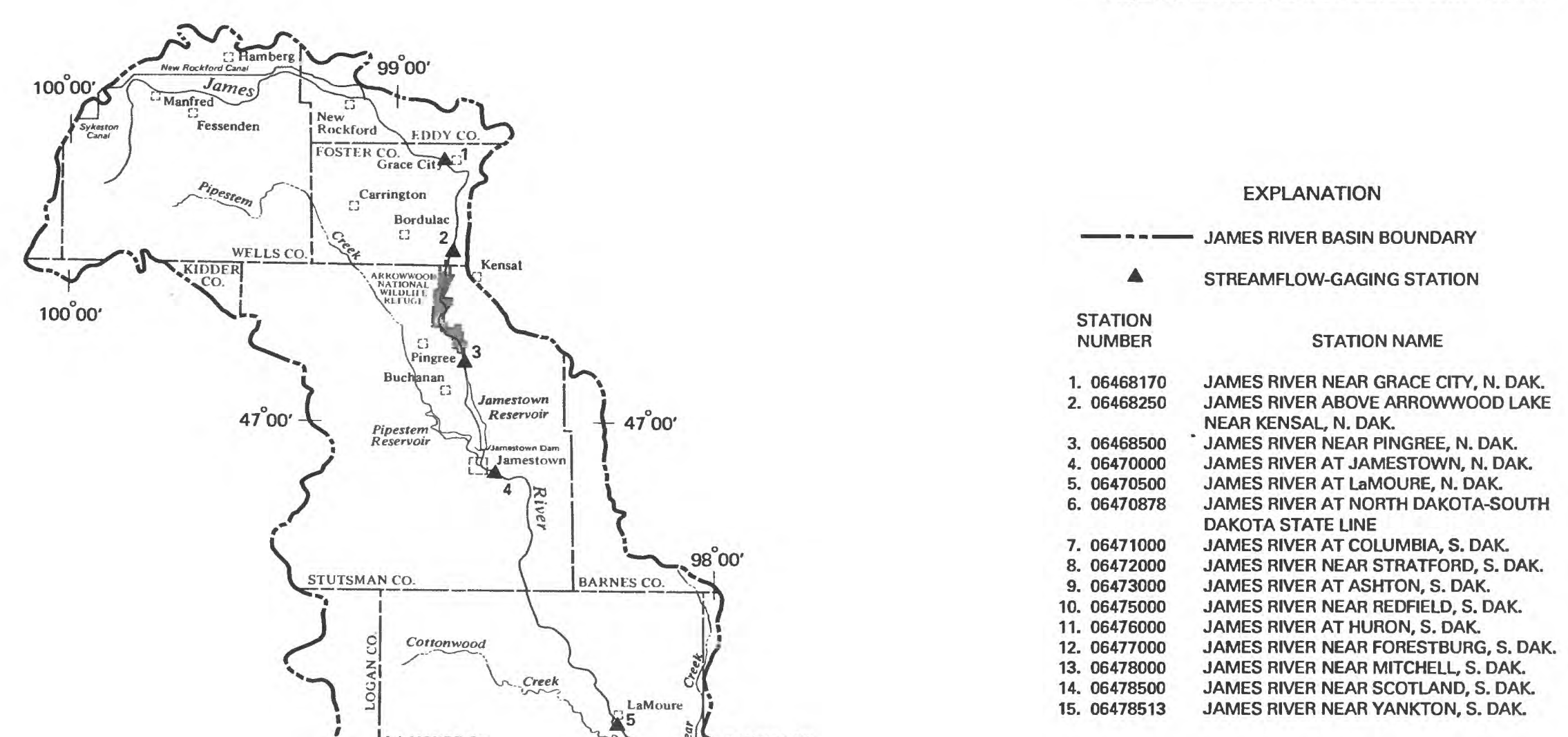

Modified from U.S Geological Surve State base maps, 1:1,000,000

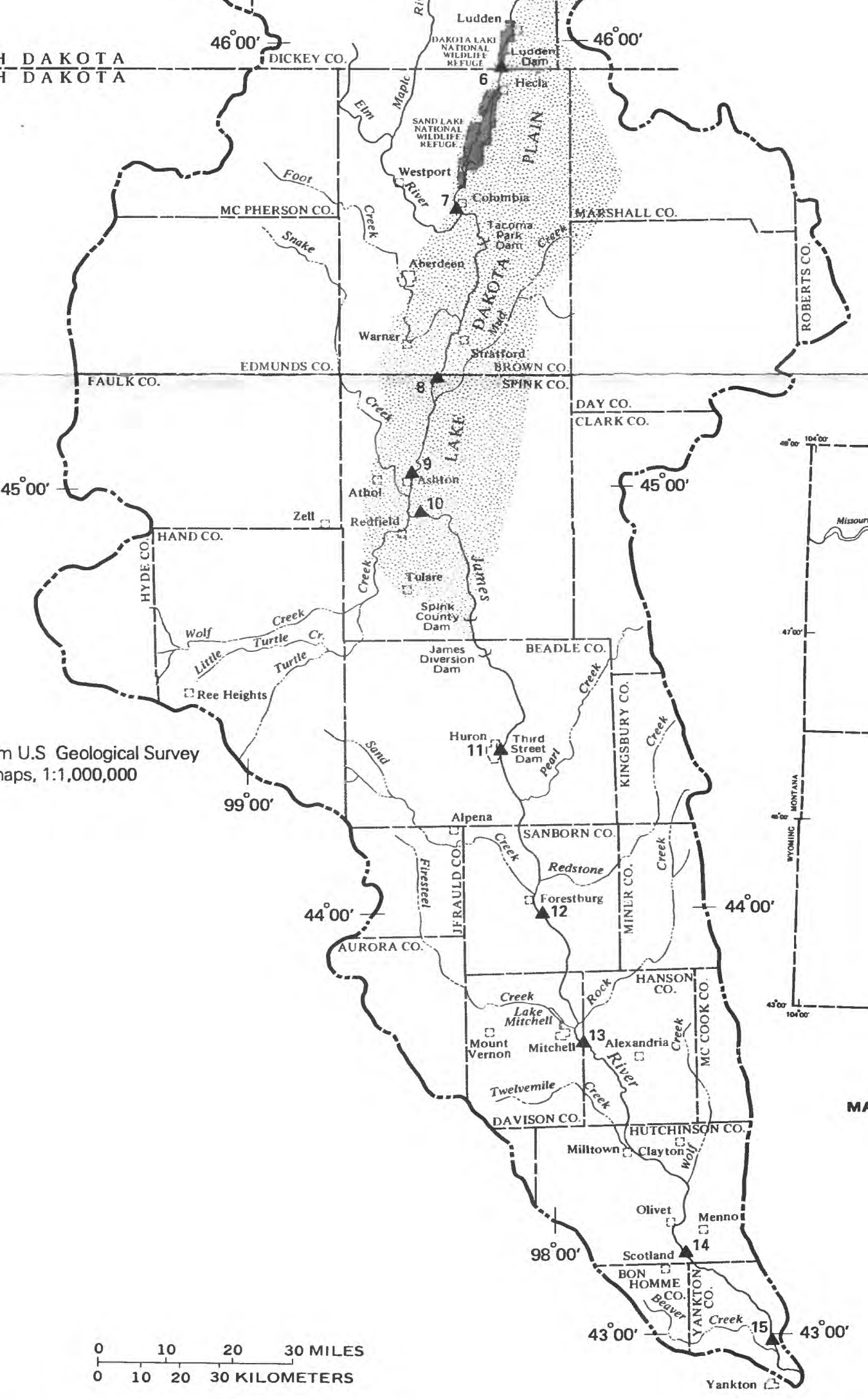

Map showing James River Basin and locations of selected streamflow-gaging stations, North Dakota and South Dakota 